\title{
PREDICTING METHANE EMISSION FROM BRYOPHYTE DISTRIBUTION IN NORTHERN CANADIAN PEATLANDS ${ }^{1}$
}

\author{
JiLl L. Bubier AND TIM R. MOORE \\ Geography Department and Centre for Climate and Global Change Research, McGill University, \\ 805 Sherbrooke Street West, Montreal, Quebec, Canada H3A 2 K6 \\ SteVe JugGins ${ }^{2}$ \\ Environmental Change Research Centre, Department of Geography, University College London, \\ 26 Bedford Way, London WCIH OAP, United Kingdom
}

\begin{abstract}
A predictive model for bryophyte distribution, water table position, and seasonal mean methane $\left(\mathrm{CH}_{4}\right)$ emission was developed for two areas of northern peatland: the Clay Belt of Ontario and the Labrador Trough of Quebec. Water table position and $\mathrm{CH}_{4}$ flux were the most important environmental variables in canonical correspondence analyses (CCA) of bryophyte data. Water chemistry constituted a second environmental gradient, independent of hydrology and $\mathrm{CH}_{4}$ flux.

Weighted averaging regression and calibration were used to develop a model for predicting $\log \mathrm{CH}_{4}$ flux from bryophyte distribution. The model showed an increase in $\log$ $\mathrm{CH}_{4}$ flux from hummock to carpet and pool species, corresponding with a decrease in height above the mean water table position. The exceptions were rich-fen pool species, which had low $\mathrm{CH}_{4}$ flux optima in spite of their moisture status. Tolerances were greatest for midhummock species and least for carpet and pool species. No overlap in tolerances occurred between hummock and pool species, suggesting that species at either end of the height gradient are the best predictors of $\mathrm{CH}_{4}$ flux.

Error analyses showed that bryophytes are equally as effective as water table position for predicting mean $\mathrm{CH}_{4}$ flux even though bryophytes are only surrogates for the degree of anaerobism/aerobism in the peat profile. Bryophytes are distributed in well-defined zones along microtopographic gradients; they integrate long-term changes in the water table, which fluctuates on a daily and seasonal basis along with $\mathrm{CH}_{4}$ flux, and may be more easily mapped with remote-sensing techniques. Bryophytes, however, are only useful for predicting $\mathrm{CH}_{4}$ flux within a region; similar species values cannot be extrapolated to other northern peatlands where different climatic and biogeochemical factors may result in different ranges of $\mathrm{CH}_{4}$ emission. The model may be used in paleoreconstructions of methane emission and for biological monitoring of climate change.
\end{abstract}

Key words: bryophytes; calibration; $\mathrm{CH}_{4}$; climate change; gradient analysis; hydrology; methane; microtopography; peatlands; predictive model; water table.

\section{INTRODUCTION}

Bryophytes are important indicators of moisture gradients in northern peatlands. As such, they may be indicators of methane emission, which is also dependent on hydrology. Many North American and European studies have found that peatland byrophytes, particularly Sphagnum species, are distributed in well-defined zones from the tops of the driest hummocks to the bottoms of hollows, carpets, and pools. Hummocks are mounds in the driest areas of peatlands, interspersed by hollows; lawns are flat areas of little relief with well-consolidated peat; carpets have emergent vegetation on loosely consolidated peat; and pools

\footnotetext{
${ }^{1}$ Manuscript received 1 December 1993; revised 24 June 1994; accepted 4 July 1994; final version received 3 August 1994.

${ }^{2}$ Present address: Department of Geography, University of Newcastle, Newcastle upon Tyne, NE1 7RU, UK.
}

are areas of open water with submergent vegetation. These studies (reviewed by Slack [1990] and Gignac [1992]) have found that bryophytes are ecological specialists in relation to moisture and water chemistry parameters. Bryophytes may also be responsible for creating the uneven hummock-hollow microtopography found in peatlands because of specific habitat requirements and their role as primary peat-formers (Vitt 1990).

Methane $\left(\mathrm{CH}_{4}\right)$, an important greenhouse gas that is produced in wetland soils, is also highly dependent on moisture conditions. Methanogenic bacteria require anaerobic conditions to produce $\mathrm{CH}_{4}$ (Cicerone and Oremland 1988); therefore, $\mathrm{CH}_{4}$ is only produced in water-logged portions of peatlands. However, as much as $90 \%$ of the $\mathrm{CH}_{4}$ that is produced below the water table can be consumed by methanotrophic bacteria in the aerated portions of the peat (King 1990). Consequently, the net flux to the atmosphere is highly dependent on 
small fluctuations in the water table. Broad-scale estimates of $\mathrm{CH}_{4}$ flux from northern wetlands have been difficult to obtain because of the spatial variability in moisture created by microtopographic features such as hummocks and hollows, an important seasonal or temporal component that involves both changes in soil temperature as well as water table levels, and the role of different substrates in the soil for bacterial activity (Moore and Knowles 1990, Morrissey and Livingston 1992, Roulet et al. 1992, Whalen and Reeburgh 1992, Bubier et al. 1993b, Dise et al. 1993, Dunfield et al. 1993, Nilsson and Bohlin 1993).

In an attempt to more accurately predict $\mathrm{CH}_{4}$ emissions from northern wetlands, various studies have examined the environmental controls responsible for production and consumption. The best predictor of total $\mathrm{CH}_{4}$ flux among a range of regional peatlands for the frost-free season is the average position of the water table (Roulet et al. 1992, Moore and Roulet 1993, Bubier et al. 1993a, Dise et al. 1993). Daily positions of the water table do not correlate with $\mathrm{CH}_{4}$ flux because of lag effects during water table fluctuations (Windsor et al. 1992), an increase in $\mathrm{CH}_{4}$ diffusivity from decreased atmospheric pressure, and a strong hysteresis on the rising and falling limbs of water table movement (Moore and Dalva 1993). Temperature also plays an important role (Crill et al. 1988, Crill et al. 1992, Dise et al. 1993), but may be more valuable in explaining the daily or seasonal pattern of $\mathrm{CH}_{4}$ emission within a single wetland rather than the relative contribution of different wetland systems over the entire season or year.

Although mean water-table position is a good predictor of mean $\mathrm{CH}_{4}$ flux among a range of wetlands in a region, it is not easy to measure because of seasonal and daily fluctuations and the small-scale variability of the depth of the aerobic zone in the peat created by hummock-hollow microtopography. As bryophytes are also good predictors of mean water-table position and are more easily identified and mapped than the fluctuating hydrologic regime, this study attempts to make the direct link between bryophyte distribution and $\mathrm{CH}_{4}$ flux in an effort to predict $\mathrm{CH}_{4}$ emission across large areas of northern peatland with less time and expense than it takes to directly measure $\mathrm{CH}_{4}$ flux in the field. The predictive relationship developed in this study focuses on the passive relationship between bryophytes and $\mathrm{CH}_{4}$ flux. It should be noted that additional research has been conducted on the active role of vascular plants in transporting $\mathrm{CH}_{4}$ to the atmosphere and in providing sites for $\mathrm{CH}_{4}$ production and consumption in the rhizosphere (e.g., Whiting and Chanton 1992).

The technique of weighted averaging regression and calibration is a simple, yet effective tool for predicting environmental variables from species assemblages in situations where direct measurement of the environmental variable is either difficult or impossible (Jongman et al. 1987). By combining ecological realism (unimodal species' responses) with empirical predictive power, weighted averaging has proved useful for palaeoenvironmental reconstructions based on a range of organisms (ter Braak and Dam 1989, Birks et al. 1990, Janssens 1990, Fritz et al. 1991, Walker et al. 1991). In comparisons, weighted averaging works best with noisy, species-rich data that have many absences in the sampling plots, and long ecological gradients ( $>3$ standard deviation units; ter Braak and Juggins 1993). The technique assumes that the environmental variables to be predicted from the species data are the most important ones in explaining species distribution (ter Braak and Dam 1989).

This study used two different areas of northern peatland to test whether bryophytes can be used as predictors of $\mathrm{CH}_{4}$ flux. The Clay Belt region of Ontario is comprised primarily of weakly minerotrophic, Sphagnum-dominated peatlands, while the more strongly minerotrophic patterned and unpatterned fens of the Labrador Trough have greater groundwater influence and are dominated by both Sphagnum and brown mosses. Earlier analyses of the species and environment data from these regions (Bubier et al. 1993a, b; Bubier, in press) showed that (1) $\mathrm{CH}_{4}$ emissions are highly variable at the microtopographic scale and that seasonal mean water-table position in hummocks and hollows, or strings and flarks (wet depressions), is the best predictor of $\mathrm{CH}_{4}$ flux among the range of Clay Belt and Labrador Trough peatlands; (2) water chemistry and hydrology are the most important environmental variables explaining species distribution in both regions, but bryophytes are more sensitive to water table position than vascular plants; (3) mean water-table position and $\mathrm{CH}_{4}$ flux are the variables correlated most strongly with bryophyte distribution in Clay Belt peatlands, while these two variables are second to water chemistry in the richer fen peatlands of the Labrador Trough; (4) there is a strong correlation between mean $\mathrm{CH}_{4}$ flux and mean water-table position in both regions, while water chemistry is an independent gradient.

The purposes of this paper are to (1) make a direct predictive link between bryophytes and $\mathrm{CH}_{4}$ flux given that both are correlated strongly with mean water-table position in northern peatlands; (2) test the robustness of weighted averaging regression and calibration as a statistical technique for predicting $\mathrm{CH}_{4}$ flux and water table position from bryophyte species assemblages; and (3) test the predictive relationship between $\mathrm{CH}_{4}$ flux and bryophytes in two different areas of northern peatland that have different chemical, hydrological, and species properties.

The predictions reported here follow from modelling the observed "response" of bryophyte taxa along environmental gradients in terms of their "optima" and "tolerances." While we realize that bryophytes probably do not respond to the methane gradient directly and do not have methane fluxes that are optimal in a biological sense, we retain the terminology for consistency with the literature on gradient analysis. 


\section{Study AREAS}

Two different areas of boreal/subarctic peatland in Canada were chosen for study: the Clay Belt peatlands near Cochrane, Ontario, were sampled in 1991 and the Labrador Trough peatlands near Schefferville, Quebec, were sampled in 1992. The Clay Belt peatlands of the mid-boreal region of Ontario (between $47^{\circ}$ and $50^{\circ} \mathrm{N}$ and between $79^{\circ}$ and $85^{\circ} \mathrm{W}$ ) are located on a flat to weakly broken clay plain that was covered by the freshwater glacial Lake Barlow-Ojibway as the Wisconsin ice sheet retreated. Most of the area is underlain by lacustrine clay, occasionally interrupted by eskers, and overlain in places by a thin surficial layer of clayey ground moraine. The poorly drained soils, relatively flat terrain, and humid boreal climate have favored the development of peatlands. Over $77 \%$ of the peatlands are treed, with conifer swamp (53\% of all peatlands) and treed bog $(23 \%)$ the most common. The remaining $24 \%$ of the peatlands are open bogs and fens, treed fens, thicket swamps, and marshes (Riley 1987). In this study 12 locations were chosen to represent the range of peatlands found in the Clay Belt and are described generally in Bubier et al. (1993a).

The Clay Belt receives $885 \mathrm{~mm}$ of precipitation annually, 33\% of which falls as snow (Environment Canada, Ottawa, Ontario, Canada, unpublished data). Approximately $80 \mathrm{~mm}$ of rain falls each month from May to October. The mean annual temperature is $0.6^{\circ} \mathrm{C}$ and the mean daily temperature for January and June is -18.3 and $16.5^{\circ} \mathrm{C}$, respectively. The May to October 1991 climate was within 1 SD of the 30-yr mean (normal), except that May and June were warmer than normal and August rainfall was $\approx 50 \%$ of normal.

The fens near Schefferville, Quebec $\left(54^{\circ} 48^{\prime} \mathrm{N}\right.$, $66^{\circ} 40^{\prime} \mathrm{W}$ ), are located in a geologically diverse area known as the Labrador Trough (Dimroth 1978). Folding and faulting of sedimentary bedrock has resulted in a ridge and valley topography about $80 \mathrm{~km}$ in width that cuts through the Canadian Shield in a northwestsoutheast direction. Wetlands occur in the valleys where drainage is impeded or groundwater upwelling creates saturated conditions necessary for peatland development. The variety of bedrock types produces variations in the water chemistry and vegetation with minerotrophic fens occurring over dolomite, rich in calcium and magnesium. Poor fens are the dominant peatland type where shale and quartzite are substrates. Within a single peatland complex the species assemblages change over short distances in response to changes in water chemistry and hydrology (Waterway et al. 1984). Patterned as well as unpatterned mires occur in the region. Most are open, with few trees except at the margins. Four peatland complexes were chosen for this study, ranging from poor to rich fen. The peatlands are known locally as Astray (or Leo), Pelletier, Capricorn, and NASA fens (Waterway et al.
1984, Moore et al. 1990, Roulet 1991, Windsor et al. 1992).

The wetlands of the Labrador Trough occur in the low subarctic peatland region of Canada (Zoltai 1988). The climate is characterized by long winters and cool, wet summers (Lechowicz and Adams 1978, Waterway et al. 1984). The 37-yr (1955-1992) mean annual temperature is $-4.9 \pm 1.1^{\circ} \mathrm{C}$ (mean $\pm 1 \mathrm{SD}$ ) with summer monthly means of $8.3 \pm 1.8^{\circ}, 12.4 \pm 1.0^{\circ}$, and 11.0 $\pm 1.3^{\circ}$ for June, July, and August, respectively (McGill Subarctic Research Station data, D. Barr, personal communication). The annual mean precipitation for the $37-$ yr period is $789 \pm 139 \mathrm{~mm}, 48 \%$ of which falls as snow. The monthly means for June, July, and August are $76.6 \pm 32.9,99.6 \pm 35.1$, and $92.8 \pm 32.6 \mathrm{~mm}$. The summer months of 1992, the main period for $\mathrm{CH}_{4}$ flux measurements, were an average of $2^{\circ}$ cooler and $30 \%$ wetter than the $37-y r$ average with monthly temperatures of $5.6^{\circ}, 10.0^{\circ}$, and $10.1^{\circ} \mathrm{C}$ and monthly precipitation of $153.8,73.4$, and $147.4 \mathrm{~mm}$ for June, July, and August, respectively. July and August were cooler than normal and June and August were wetter by $>1$ SD. June 1992 precipitation was a new maximum for the month.

\section{METHODS}

\section{Vegetation sampling}

Approximately $10050 \times 50 \mathrm{~cm}$ vegetation plots were chosen randomly from among the preselected peatland complexes in each of the study areas, representing the range of peatland vegetation in the Clay Belt and the Labrador Trough. Bryophyte sampling was in the form of percentage canopy cover (Daubenmire 1968). Nomenclature follows Anderson et al. (1990) for mosses, Anderson (1990) for Sphagnum species, and Stotler and Crandell-Stotler (1977) for liverworts. Voucher specimens are deposited in the herbaria of either J. Bubier, J. Janssens, or McGill University.

\section{Methane emission measurements}

$\mathrm{CH}_{4}$ flux was measured at 100 randomly selected chamber locations every $7-10 \mathrm{~d}$ in each region for the major period of methane emission. The wetlands chosen for study covered the range of moisture and chemistry gradients for both regions. In the Clay Belt, $\mathrm{CH}_{4}$ flux was measured from May until the end of August, resulting in 8-10 measurements at each of the 100 sampling points. In the Labrador Trough, the sampling season was from June to the end of August, corresponding to the shorter frost-free period, and resulted in 7-9 measurements per chamber. Seasonal mean fluxes were calculated in both areas by averaging the weekly measurements.

$\mathrm{CH}_{4}$ flux was measured using polycarbonate $18-\mathrm{L}$ static chambers by the method outlined in Moore and Roulet (1991). The chamber was covered with aluminum foil to reduce heating. Air samples were collected 
by inserting a $10-\mathrm{mL}$ syringe into a septum stopper in the top of the chamber, pumping the piston several times to mix air in the chamber before an air sample was withdrawn. The chambers were placed gently into the peat or into fixed collars to minimize disturbance. An initial air sample was taken with the syringe, then a final sample taken after the chamber remained in place for $\approx 2 \mathrm{~h}$.

Air samples were analyzed within $24 \mathrm{~h}$ of collection. $\mathrm{CH}_{4}$ concentrations were determined on a Shimadzu Mini 2 gas chromatograph, using a 5-mL sample, a 1-mL injection loop and a Poropak-Q column (80/100 mesh, $3 \mathrm{~m} \times 3 \mathrm{~mm}$ ) at $40^{\circ} \mathrm{C}$. Helium was used as the carrier gas at a flow rate of $30 \mathrm{~mL} / \mathrm{min}$, and $\mathrm{CH}_{4}$ standards of 2 and $500 \mu \mathrm{L} / \mathrm{L}$ were employed. $\mathrm{CH}_{4}$ fluxes were calculated from the difference between initial and final concentrations over the 2-h sampling period, corrected for the volume of air in the chamber and air temperature. The accuracy of the gas chromatograph was $\pm 50 \mathrm{~nL} / \mathrm{L}$. Fluxes between 0.1 and -0.1 $\mathrm{mg} \cdot \mathrm{m}^{-2} \cdot \mathrm{d}^{-1}$ were not detectable. When the initial concentration exceeded $2 \mu \mathrm{L} / \mathrm{L}$ (ambient) and the final concentration was lower than the inital, the sample was rejected. Fewer than $3 \%$ of the samples were rejected.

\section{Environmental variables}

Water table position was measured on each methane sampling date with piezometers placed within each vegetation stand. The height of each chamber location relative to water table was measured with a tube level referenced to the nearest piezometer. Mean seasonal water-table position for each of the 100 sampling locations was determined by averaging the weekly measurements. The temperature of the peat was measured weekly at $10-\mathrm{cm}$ increments from the surface to $50 \mathrm{~cm}$ depth with a thermistor rod.

Water chemistry was analyzed from samples of peatland surface water collected within each vegetation stand in either standing water or in wet areas where the peat surface was depressed slightly. Samples were collected in triple acid-washed polyethylene bottles and analyzed for $\mathrm{pH}$ and specific conductance immediately after removal from the field. Conductivity measurements were adjusted to $20^{\circ} \mathrm{C}$ and corrected for hydrogen ion concentrations $\left(K_{\text {corr }}\right)$ (Sjörs 1950). Samples were filtered, stored at $4^{\circ} \mathrm{C}$ and analyzed later by atomic absorption spectrophotometry for calcium (Ca), magnesium $(\mathrm{Mg})$, sodium $(\mathrm{Na})$, and potassium $(\mathrm{K})$ concentrations.

\section{Data analyses}

Preliminary analyses of $\mathrm{CH}_{4}$ flux and water table data in the two regions (Bubier et al. 1993a; Bubier, in press) revealed that seasonal mean water-table position was significantly correlated with seasonal mean $\mathrm{CH}_{4}$ flux based on averages of hummock, hollow, and lawn microtopographic groupings within each peatland site. In this study, regression analyses were run on mean water-table position and $\mathrm{CH}_{4}$ flux for the 100 specific plots in each study area to see if the relationship is still strong when spatial variability is not averaged in the analysis.

Canonical correspondence analysis (CCA; ter Braak 1986) of the averaged species and environmental data showed that most of the variability in the vegetation of both study areas could be explained statistically by two sets of environmental variables: the height above mean water table (HMWT) and its inverse correlate $\mathrm{CH}_{4}$ flux, and water chemistry variables reflecting total mineral content (Bubier, in press). In addition, the bryophytes were more strongly correlated with water table position and $\mathrm{CH}_{4}$ flux than were the vascular plants.

To further investigate the species-environment relationships and the potential predictive relationships between bryophytes and $\mathrm{CH}_{4}$ flux in the individual plots, we performed (1) CCAs with HMWT, $\mathrm{CH}_{4}$ flux, and $K_{\text {corr }}$ as the constraining variables, and (2) a series of partial CCAs to partition the variance in the species data among these three explanatory environmental variables to estimate their relative strength and independence (cf. Borcard et al. 1992). $K_{\text {corr }}$ was retained as the only hydrochemical variable to reduce redundancy in the explanatory variables. Previous analyses showed that it is a good surrogate for $\mathrm{pH}$ and cations, reflecting total mineral content. Monte Carlo permutation tests (99 unrestricted permutations) were used to test the significance of the relevant CCA axes.

Based on the constrained environmental variables in the CCA analysis, a model for predicting $\log \mathrm{CH}_{4}$ flux and water table position from bryophyte distribution was developed using weighted-averaging (WA) regression and calibration (Jongman et al. 1987, ter Braak and Dam 1989). WA assumes that the environmental variables are the most important ones derived from the $\mathrm{CCA}$ analysis. The theory behind WA regression is that a species has a unimodal response to a given environmental variable; that is, the species reaches its maximum abundance at its preferred or optimum position in relation to the environmental variable. The WA method consists of three parts: WA regression, WA calibration, and a deshrinking regression (ter Braak and Juggins 1993).

1) WA regression: The WA estimate of a species optimum is the average of all values of the environmental variable ( $x$ values of the sites) for the species, weighted by the species abundance:

$$
\hat{u}_{k}=\sum_{i=1}^{m} y_{i k} x_{i} / \sum_{i=1}^{n} y_{i k}
$$

where $y_{i k}$ is the abundance of species $k$ in sample $i$, $x_{i}$ is the observed value of the environmental variable of sample $i$, and $u_{k}$ is the optimum. The tolerance $\left(t_{k}\right)$ or weighted standard deviation for a species is: 
TABle 1. Summary of Clay Belt and Labrador Trough bryophyte data sets: (A) Species, samples, and $\mathrm{CH}_{4}$ flux statistics. (B) Canonical coefficients, their $t$ test values, and intra-set correlations of the environmental variables (height above mean water table (HMWT), mean $\mathrm{CH}_{4}$ flux, and corrected conductivity $\left[K_{\text {corr }}\right]$ ) for canonical correlation analysis (CCA) axes 1 and 2. (C) Percentage of variation of the bryophyte data that is explained by the environmental variables.

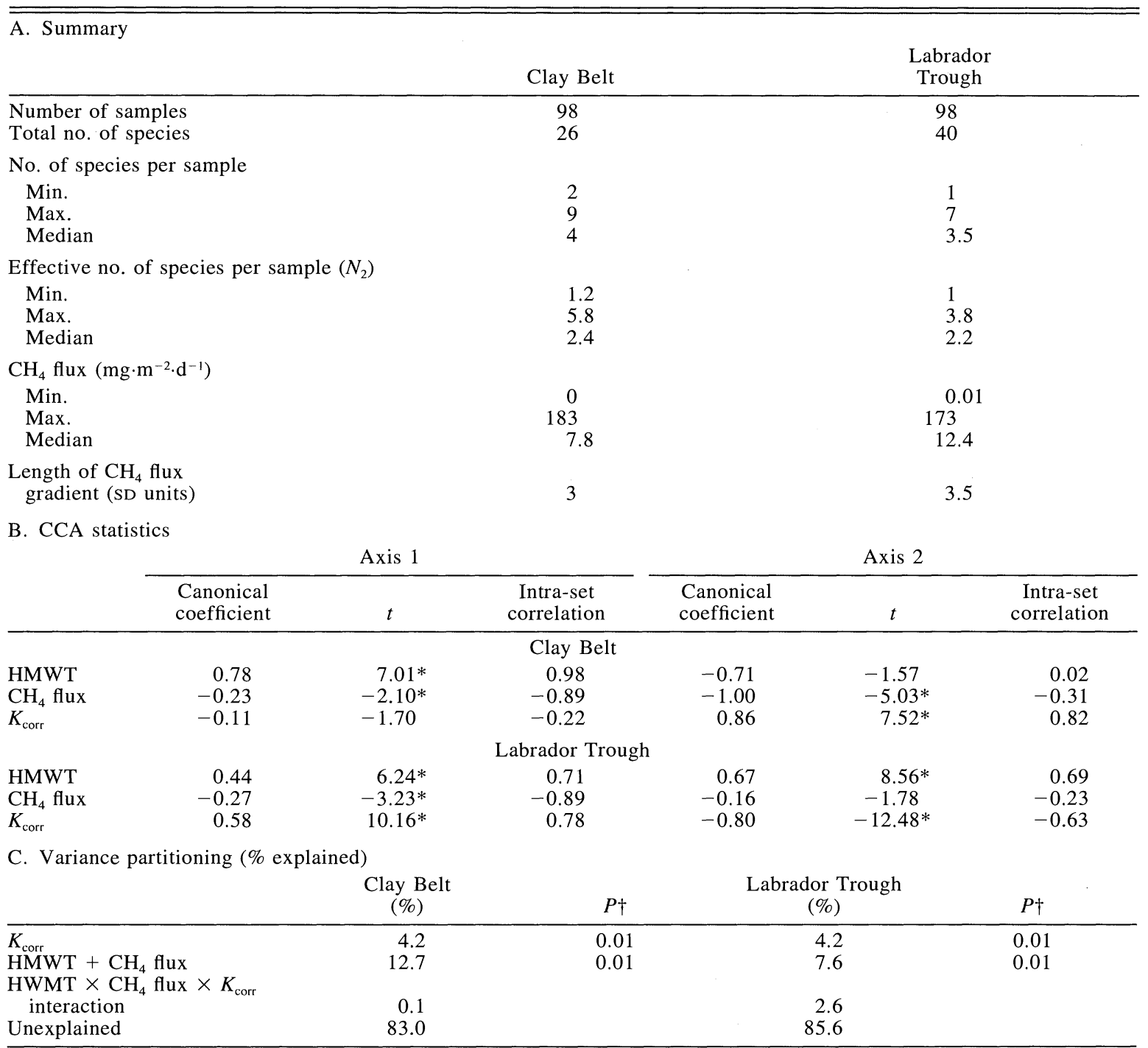

$* P=0.05$.

† Significance values are based on 99 unrestricted Monte Carlo permutations, with all other environmental variables used as covariables.

$$
\hat{t}_{k}=\left[\sum_{i=1}^{n} y_{i k}\left(x_{i}-\hat{u}_{k}\right)^{z} / \sum_{i=1}^{n} y_{i k}\right]^{1 / 2} .
$$

2) WA calibration: Estimate the environmental variable values ( $x$ values of the sites) by weighted averaging of the species optima:

$$
x_{i}=\sum_{k} y_{i k} u_{k} / y_{i k} \text {. }
$$

3) Deshrinking regression: Regress the environmental variables $\left(x_{i}\right)$ on the preliminary estimates $\left(x_{i}^{*}\right)$ and take the fitted values as the estimate of $x_{i}$. In weighted averaging reconstructions, averages are taken twice, and the range of the predicted environmental values is shrunken. This is corrected by performing either an "inverse deshrinking" regression of observed on inferred values, or a "classical deshrinking" of inferred on observed values. The former minimizes the mean squared error in the data set, but introduces bias at the ends of the gradient; extreme environmental values are underestimated (Birks et al. 1990, Osborne 1991). Since we want our calibrations to be most precise at high methane fluxes, classical deshrinking was used.

The performance of the different models was measured by the correlation between observed and esti- 


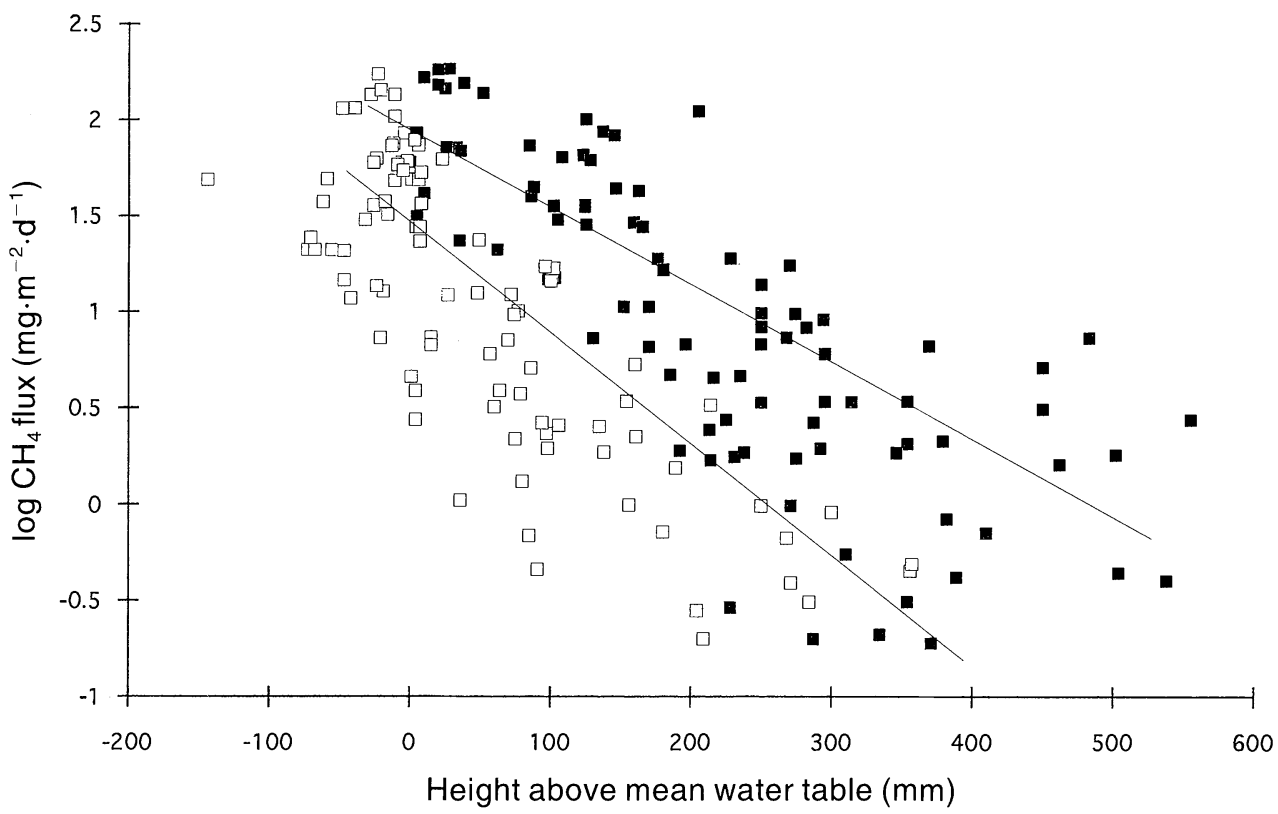

FIG. 1. The relationship between height above mean water table (HMWT) and $\log \mathrm{CH}_{4}$ flux in two areas of northern Canada peatland. Methane flux was measured in milligrams per square metre per day. Clay Belt peatlands (solid symbols): $\log \mathrm{CH}_{4}$ flux $=-0.004$ HMWT $+1.89 ; r^{2}=0.68 ; P<0.001 ;$ RMSE for $\log \mathrm{CH}_{4}$ flux $=0.38 ; n=98$. Labrador Trough peatlands (open symbols): $\log \mathrm{CH}_{4}$ flux $=-0.006 \mathrm{HMWT}+1.30 ; r^{2}=0.62 ; P<0.001 ; \mathrm{RMSE}$ for $\log \mathrm{CH}_{4}$ flux $=0.49$; $n=95$.

mated values and by the root mean squared error (RMSE) of the estimated values (Birks et al. 1990). To facilitate comparisons the two data sets are described in terms of total number of taxa; the number of taxa per sample; the effective number of taxa per sample (Hill's $N_{2}$, Hill 1973), which gives a measure of the number of taxa per sample contributing to the weighted average calculations; and the length of the methane flux gradient in standard deviation (SD) units (Hill and Gauch 1980), which gives a measure of species turnover along the gradient.

Methane flux and corrected conductivity $\left(K_{\text {corr }}\right)$ were $\log _{10}$ transformed prior to multivariate analyses because they were skewed. The bryophyte data were transformed to an eight-point van der Maarel scale $(0.1,2$, $5,10,25,50,75,100)$ prior to all analyses. Ordinations were performed using the program CANOCO (ter Braak 1990), and weighted averaging using the program CALIBRATE (S. Juggins and C. J. F. ter Braak, unpublished computer program, version 1.0, Environmental Change Research Centre, University College, London, England).

\section{RESULTS}

Table 1A summarizes the two bryophyte data sets. The Labrador Trough has a greater overall species diversity with a total of 40 taxa recorded, although individual plot diversity is comparable between areas with a median diversity of 4 taxa per plot and those with a median of 2.2-2.4 effective occurrences. The range of methane fluxes and the methane gradient length of 3.0-3.5 SD units is also similar between areas although the Clay Belt data set is more biased towards lower methane fluxes.

\section{$\mathrm{CH}_{4}$ flux-water table relationships}

The relationships between height above mean water table and $\log \mathrm{CH}_{4}$ flux for the 100 plots in each of the Clay Belt and the Labrador Trough study areas are remarkably similar, with correlation coefficients $\left(r^{2}\right)$ of 0.68 or $0.62(P<0.001)$ and slopes of the regression lines of -0.006 and -0.004 , respectively, indicating a similar functional relationship between $\mathrm{CH}_{4}$ flux and water table position within both regions (Fig. 1). The intercepts are different (1.30 and 1.89 , respectively), however, suggesting that between regions the relationship has some differences. For the same water-table position, the Clay Belt peatlands have higher $\mathrm{CH}_{4}$ fluxes than those of the Labrador Trough.

\section{Canonical correspondence analyses}

Canonical correspondence analysis (CCA) of the Clay Belt data set (Fig. 2 and Table 1B) shows that axis 1 (eigenvalue of axis $1=0.46, P=0.01$ ) is strongly correlated with height above mean water table (HMWT) and $\mathrm{CH}_{4}$ flux (intra-set correlations of 0.98 and -0.89 , respectively) and that axis 2 (eigenvalue $=0.23, P=0.01)$ is correlated with water mineral content $\left(K_{\text {corr }}\right)$ (intra-set correlation 0.82$)$. For the Labrador Trough axis 1 (eigenvalue $=0.79, P=0.01$ ), 


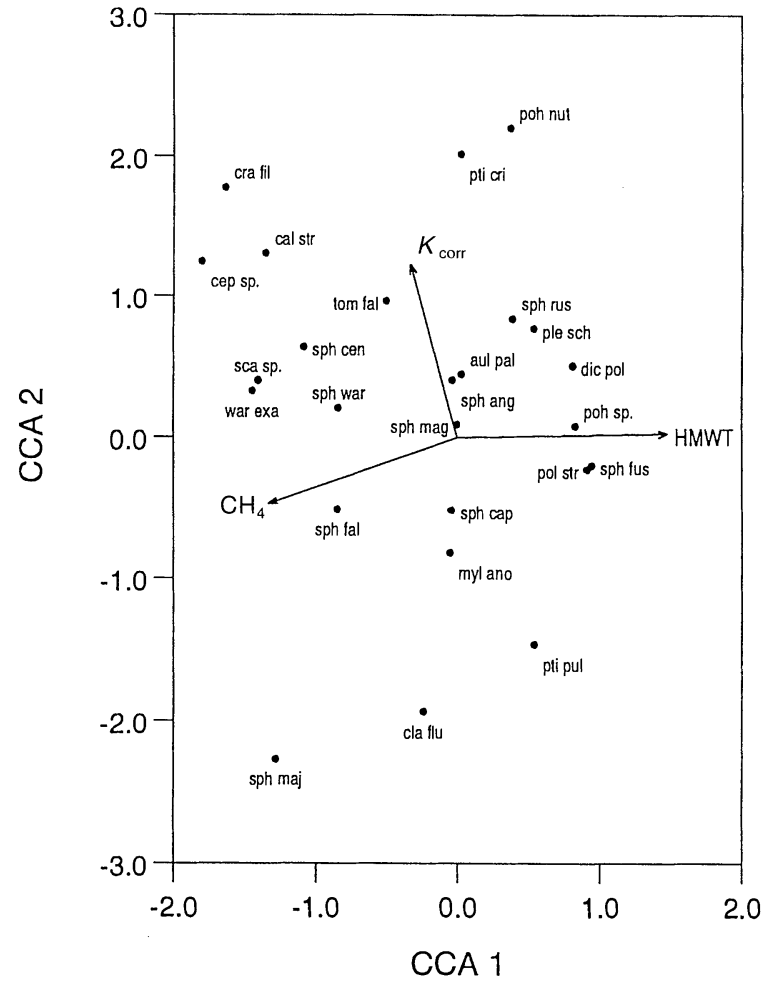

FIG. 2. Canonical correspondence analysis (CCA) of Clay Belt bryophytes in relation to $\mathrm{CH}_{4}$ flux, corrected conductivity $\left(K_{\text {corr }}\right)$, and height above mean water table (HMWT). Species codes are defined in Table 2. Eigenvalues for CCA axes 1 and 2 are 0.46 and 0.23 , respectively.

conductivity, HMWT, and methane flux all make significant contributions to, and are highly correlated with, axis 1 (intra-set correlation $0.78,0.71$, and -0.89 , respectively), while HMWT and conductivity are significantly correlated with axis 2 (eigenvalue $=0.63, P=$ 0.01 ; intra-set correlations 0.69 and -0.63 , respectively) (Fig. 3, Table 1B). For both data sets, a Monte Carlo permutation test showed the first axis is significant at $P=0.01$.

In both CCA analyses the relationships between individual bryophyte species and environmental variables are discovered by drawing a perpendicular line from the species point to the arrow representing the environmental variable of interest. For example, in the Clay Belt (Fig. 2), Sphagnum majus, S. fallax, and Warnstorfia exannulatus are positioned at the high end of the $\mathrm{CH}_{4}$ flux arrow and the low end of the HMWT arrow (if the HMWT arrow is extended in the opposite direction). The intersection of the $x$ and $y$ axes represents the centroid or grand mean of each of the environmental variables. Dicranum polysetum, Polytrichum strictum, and $S$. fuscum, for example, have low $\mathrm{CH}_{4}$ fluxes and are positioned high above the water table. In the Labrador Trough (Fig. 3) S. fallax, S. annulatum, and $W$. exannulatus are correlated with the highest $\mathrm{CH}_{4}$ fluxes and wettest conditions, while S. fuscum, Pleu- rozium schreberi and $D$. undulatum are the driest and lowest $\mathrm{CH}_{4}$ flux indicator species.

Results of the variance partitioning show that the three environmental variables explain $17 \%$ of the total variance in the bryophyte data in the Clay Belt and $14.4 \%$ in the Labrador Trough (Table 1C). This low percentage of variance explained is due to the presence of many zero values in the data (compare the total number of taxa in the data sets with the median number in a single plot [Table 1A]), and is typical for such noisy data sets representing long environmental gradients (e.g., Dixit et al. 1993). In both areas, HMWT and $\mathrm{CH}_{4}$ flux are strongly negatively correlated and taken separately do not make significant independent contributions to explaining the species data when the effects of the remaining variables are partialled out. For the purposes of the variance partitioning we therefore consider these variables together as a single composite gradient. In the partial CCAs this was done by including both as explanatory variables and $K_{\text {corr }}$ as a single covariable and vice versa.

In the Clay Belt the HMWT $+\mathrm{CH}_{4}$ flux and conductivity gradients are virtually independent, with the former dominant and accounting for $12.7 \%$ of the species variance. In the Labrador Trough there is some dependence between HMWT $+\mathrm{CH}_{4}$ flux and conductivity, with the former accounting for $10.2 \%$ of the variance, of which $2.6 \%$ is conditioned on conductivity. The results of the partial CCAs in Table 1C indicate that both HMWT $+\mathrm{CH}_{4}$ flux and conductivity explain significant and independent portions of the species data for the individual plots, and suggest that predictive models may be developed for both areas for HMWT and $\mathrm{CH}_{4}$ flux.

\section{Weighted-averaging regression and calibration}

Given that water table position and $\mathrm{CH}_{4}$ flux are the first or second most important variables associated with bryophyte distribution, a weighted-averaging (WA) regression analysis was performed to determine the optimum and tolerance of each species for these two variables. WA optima and tolerances for all taxa in the two data sets are presented in Table 2 and shown graphically in Figs. 4 and 6. In the Clay Belt (Fig. 4), the HMWT and $\mathrm{CH}_{4}$ flux optima and tolerances for individual species show a distinct trend along the moisture gradient from the top hummock species to the wettest carpet or pool species. The species are arranged in order of optimum values; however their tolerances (abundanceweighted standard deviations) vary widely. The largest tolerances occur with the mid-hummock and lawn species for both HMWT and $\log \mathrm{CH}_{4}$ flux. The wettest indicator species have the lowest tolerances, which is important in light of the fact that they indicate the highest $\mathrm{CH}_{4}$ fluxes, and the $\log$ of $\mathrm{CH}_{4}$ flux indicates a larger range of methane values at the higher end of the scale. There is also no overlap in tolerances between hummock and carpet species, further strengthening the 


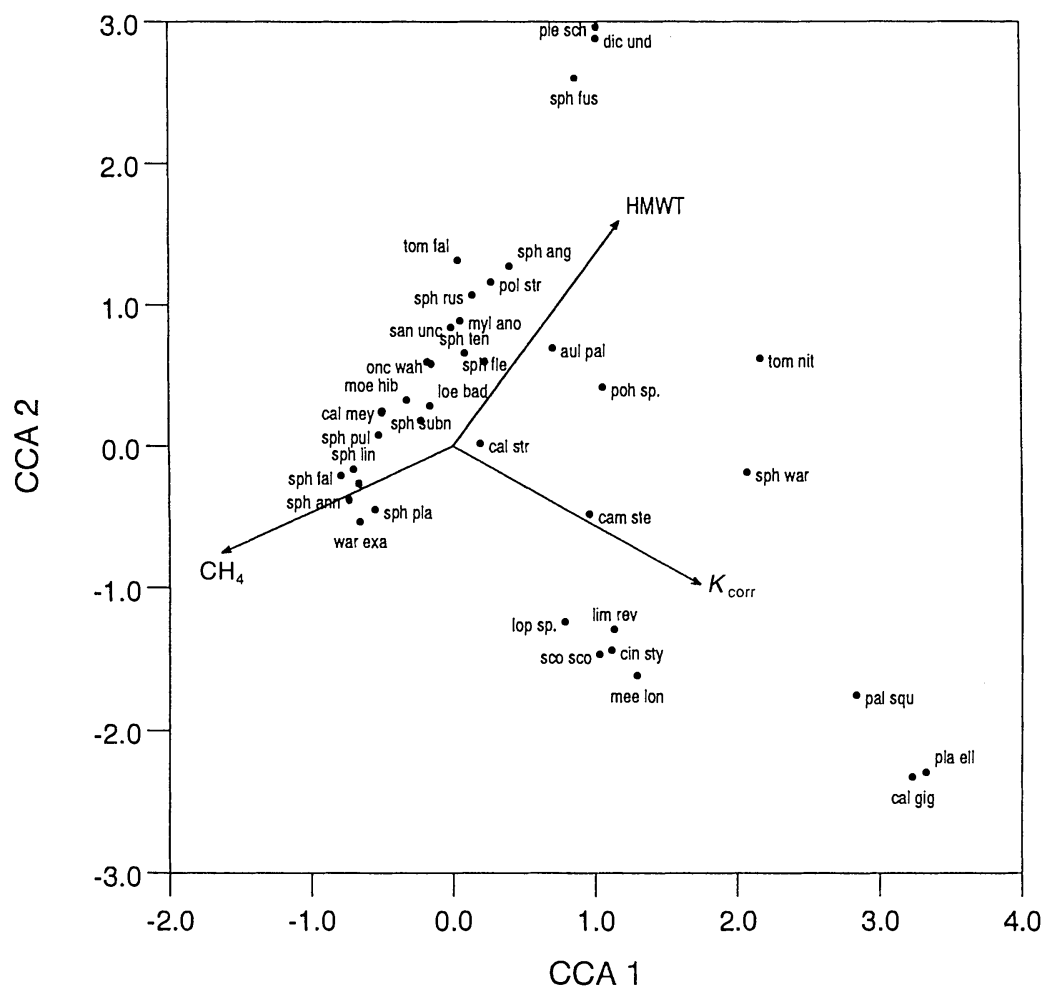

FIG. 3. Canonical correspondence analysis (CCA) of Labrador Trough bryophytes in relation to $\mathrm{CH}_{4}$ flux, $K_{\text {corr }}$, and height above mean water table (HMWT). Species codes are defined in Table 2. Eigenvalues for CCA axes 1 and 2 are 0.79 and 0.63 , respectively.

predictive ability of bryophyte species at either end of the moisture gradient.

In the program CALIBRATE (S. Juggins and C. J. F. ter Braak, unpublished), tolerances are adjusted for the number of occurrences; therefore, tolerances for species with a low number of occurrences (Table 2) are higher than they would otherwise receive. Although the $\mathrm{CH}_{4}$ flux tolerances for Cratoneuron filicinum, Calliergon stramineum, and Sphagnum centrale are large in Fig. 4, they are overestimated because of their low number of occurrences. In contrast, a species with a high number of occurrences such as Sphagnum magellanicum has a realistically large $\mathrm{CH}_{4}$ flux tolerance because of its wide range along the moisture gradient.

The plots of individual species distributions for selected species in relation to HMWT and $\log \mathrm{CH}_{4}$ flux (Fig. 5) are shown with Gaussian curves fitted to the data. Sphagnum fallax, a carpet species, has a higher optimum and smaller tolerance for $\log \mathrm{CH}_{4}$ flux than S. angustifolium, a lawn or hollow species. The same relationship occurs for HMWT in both species. The hummock species, S. fuscum has much lower $\log \mathrm{CH}_{4}$ flux and higher HMWT optima than the lawn or carpet species, but its tolerances are also wide.

The optima and tolerances for Labrador Trough bryophytes (Table 2, Fig. 6) show a similar inverse relationship between HMWT and $\log \mathrm{CH}_{4}$ flux for each of the species, but the ordering of species is not as closely tied to the moisture gradient as in the Clay Belt. Several non-Sphagnum pool species that have low optima for HMWT (i.e., occur where the water table is close to the peat surface) do not have correspondingly high $\log \mathrm{CH}_{4}$ fluxes. Pool species such as Limprichtia revolvens, Meesia longiseta, and Scorpidium scorpioides all occur in the mid-range of log $\mathrm{CH}_{4}$ flux. These species are found in only the richest Labrador Trough fens. The relative order of Sphagnum species for water table position and $\log \mathrm{CH}_{4}$ flux, however, is similar to the Clay Belt (Fig. 6), with Sphagnum fuscum at the opposite end of the spectrum from carpet species $S$. annulatum, $S$. pulchrum, and $S$. lindbergii. Graphs of common string and carpet/pool Sphagnum species (Fig. 7) show that $S$. lindbergii, a widespread carpet species of poor fens, has a greater optimum and smaller tolerance for $\log \mathrm{CH}_{4}$ flux than $S$. russowii, a species of low hummocks and strings of both poor and rich fens.

Results of the WA calibration models for $\mathrm{CH}_{4}$ flux and HMWT are listed in Table 3. Weighted averaging with tolerance downweighting (WA-TOL) gave the best performance for both variables in both data sets, with the highest correlation between observed and inferred $\mathrm{CH}_{4}$ flux, and the lowest root mean squared error 

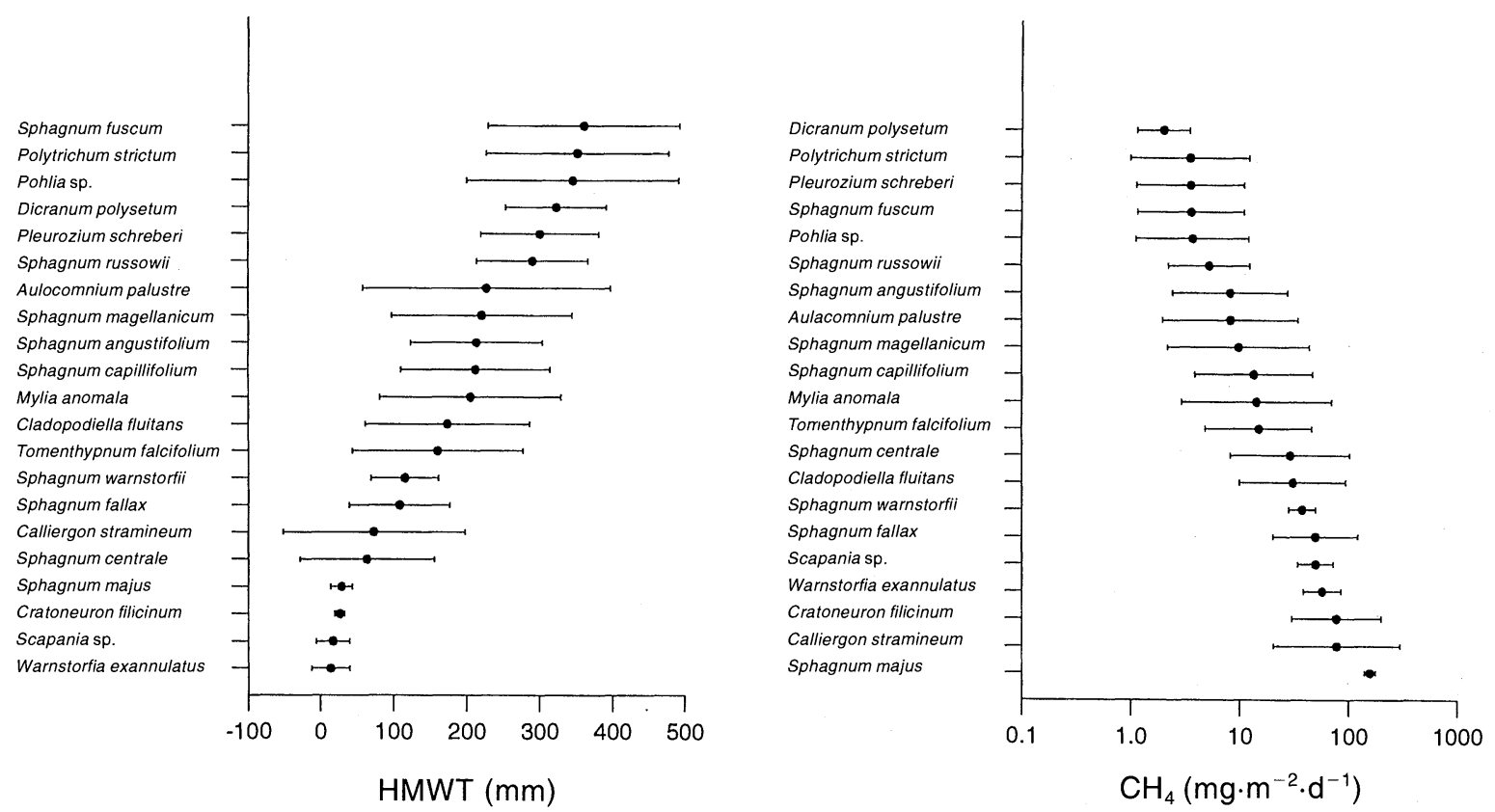

FIG. 4. Weighted average optima (central point: abundance-weighted means) and tolerances (bars: abundance-weighted SDs) of Clay Belt bryophytes for height above mean water table (HMWT) and $\mathrm{CH}_{4}$ flux for all taxa with $>2$ occurrences.

(RMSE) of prediction. The relationships between observed and inferred values for the models are shown in Figs. 8A-D.

For the Clay Belt, correlation coefficients $\left(r^{2}\right)$ for predicted vs. observed HMWT and $\log \mathrm{CH}_{4}$ flux with WA-TOL were 0.75 and 0.70 , respectively (Table 3 ; Fig. 8A, B); the RMSE for each of these analyses was 83.3 and 0.44 , respectively. By placing the best-fitting regression line on the graphs, it appears that the model underestimates $\log \mathrm{CH}_{4}$ flux at the mid-range values $\left(10-100 \mathrm{mg} \cdot \mathrm{m}^{-2} \cdot \mathrm{d}^{-1}\right)$. The opposite (overestimation at mid-ranges) is true for HMWT, although the model underestimates HMWT for the very wettest samples where the water table is near 0 .

For the Labrador Trough sample plots (Table 3; Fig. $8 \mathrm{C}, \mathrm{D}), r^{2}=0.88$ for predicted vs. observed HMWT with RMSE of 37.8. For predicted vs. observed log $\mathrm{CH}_{4}$ flux, $r^{2}=0.79$ and $\mathrm{RMSE}=0.46$. The correlation coefficients are higher than those of the Clay Belt and the errors are lower or similar, indicating a better fit of the model. The scattering of plots in relation to the best-fitting regression lines shows that for both HMWT and $\log \mathrm{CH}_{4}$ flux the fit of the model is very good.

\section{Discussion}

The relationship between water table position and $\log \mathrm{CH}_{4}$ flux in the two northern Canadian peatland regions shows similar correlation coefficients and slopes of the best-fitting regression line (Fig. 1). The intercept of the line for the Clay Belt peatlands is higher than that for the Labrador Trough fens. Moore and Roulet (1993) also reported similar regression coeffi- cients and slopes, but different intercepts, for peatlands from several Canadian regions. For the Clay Belt, a higher intercept than that for the Labrador Trough indicates greater $\mathrm{CH}_{4}$ emissions for comparable water table positions. A likely explanation would be that lower annual temperatures of the Labrador Trough fens result in less microbiological activity in the peat and lower $\mathrm{CH}_{4}$ fluxes; however, soil temperature alone did not explain the differences in the $\log \mathrm{CH}_{4}$ flux-water table relationship between these two regions (Bubier, in press) or in the Canadian survey (Moore and Roulet 1993). Nonetheless, 1992 was a cooler-than-average year in the Labrador Trough, and 1991 was warmer than average in the Clay Belt, which could contribute to the regional differences in $\mathrm{CH}_{4}$ emissions. Previous years' research in the Labrador Trough showed higher $\mathrm{CH}_{4}$ fluxes in Capricorn fen than in 1992 (Moore et al. 1990, Windsor et al. 1992).

Another possible explanation is the difference in peat types, composed of different plant materials with differing degrees of decomposition and hydraulic conductivities. The Labrador Trough peats have a larger sedge component, particularly Carex, which has been associated with lower methane concentrations than peats composed of Sphagnum (Nilsson and Bohlin 1993), the dominant type of the Clay Belt. The fens of the Trough also have greater groundwater input and oxygen, which could accelerate decomposition. Moredecomposed peats have less fresh plant material for methanogens and may yield lower $\mathrm{CH}_{4}$ emissions. The more dense sedge peat of the Trough fens also has lower hydraulic conductivity (Boelter 1965) than Sphagnum 
TABLE 2. Summary statistics (weighted-average [WA] optima and tolerances) for bryophyte taxa in the Clay Belt (Ontario) and the Labrador Trough (Quebec) peatlands of northern Canada. $N=$ number of occurrences; Max $=$ maximum abundance

\begin{tabular}{|c|c|c|c|c|c|c|c|}
\hline \multirow[b]{3}{*}{ Code } & \multirow[b]{3}{*}{ Taxon } & \multicolumn{6}{|c|}{ Clay belt } \\
\hline & & \multirow[b]{2}{*}{$N$} & \multirow[b]{2}{*}{ Max } & \multirow[b]{2}{*}{$\mathrm{N}_{2}$} & \multicolumn{3}{|c|}{ HMWT (mm) } \\
\hline & & & & & Opt - tol & Optimum & $\mathrm{Opt}+\mathrm{tol}$ \\
\hline aul pal & Aulacomnium palustre & 18 & 3 & 15.2 & 58.6 & 228.4 & 398.2 \\
\hline cal gig & Calliergon giganteum & $\cdots$ & $\cdots$ & $\cdots$ & $\cdots$ & $\cdots$ & $\ldots$ \\
\hline cal mey & Calypogeia meylanii & $\ldots$ & $\ldots$ & $\ldots$ & $\ldots$ & $\ldots$ & $\ldots$ \\
\hline cal str & Calliergon stramineum & 3 & 5 & 1.8 & -51.8 & 73.1 & 198.0 \\
\hline cam ste & Campylium stellatum & $\cdots$ & $\cdots$ & $\cdots$ & $\cdots$ & $\ldots$ & $\cdots$ \\
\hline cep sp. & Cephalozia sp. & 1 & 1 & 1.0 & $\cdots$ & 20.0 & $\cdots$ \\
\hline cin sty & Cinclidium stygium & $\ldots$ & $\ldots$ & $\cdots$ & $\ldots$ & $\cdots$ & $\cdots$ \\
\hline cla flu & Cladopodiella fluitans & 7 & 6 & 4.4 & 61.9 & 174.3 & 286.7 \\
\hline cra fil & Cratoneuron filicinum & 3 & 8 & 2.9 & 18.7 & 26.0 & 33.3 \\
\hline dic pol & Dicranum polysetum & 3 & 1 & 3.0 & 254.6 & 323.7 & 392.8 \\
\hline dic und & D. undulatum & $\cdots$ & $\cdots$ & $\cdots$ & $\cdots$ & $\cdots$ & $\cdots$ \\
\hline dre adu & Drepanocladus aduncus & $\cdots$ & $\cdots$ & $\cdots$ & $\cdots$ & $\cdots$ & $\cdots$ \\
\hline lim rev & Limprichtia revolvens & $\cdots$ & $\cdots$ & $\cdots$ & $\cdots$ & $\cdots$ & $\cdots$ \\
\hline loe bad & Loeskhypnum badium & $\cdots$ & $\cdots$ & $\cdots$ & $\cdots$ & $\cdots$ & $\cdots$ \\
\hline lop sp. & Lophozia sp. & $\cdots$ & $\cdots$ & $\cdots$ & $\cdots$ & $\cdots$ & $\cdots$ \\
\hline mee lon & Meesia longiseta & $\cdots$ & $\cdots$ & $\cdots$ & $\cdots$ & $\cdots$ & $\cdots$ \\
\hline moe hib & Moerkia hibernica & $\cdots$ & $\cdots$ & $\cdots$ & $\cdots$ & $\cdots$ & $\cdots$ \\
\hline myl ano & Mylia anomala & 10 & 6 & 6.4 & 81.6 & 205.8 & 330.0 \\
\hline onc wah & Oncophorus wahlenbergii & $\cdots$ & $\cdots$ & $\cdots$ & $\cdots$ & $\cdots$ & $\cdots$ \\
\hline pal squ & Paludella squarrosa & $\cdots$ & $\cdots$ & $\cdots$ & $\cdots$ & $\cdots$ & $\cdots$ \\
\hline pla ell & Plagiomnium ellipticum & $\cdots$ & $\cdots$ & $\cdots$ & $\cdots$ & $\ldots$ & $\cdots$ \\
\hline ple sch & Pleurozium schreberi & 12 & 8 & 7.4 & 220.7 & 301.5 & 382.3 \\
\hline poh nut & Pohlia nutans & 1 & 1 & 1.0 & $\ldots$ & 314.0 & $\ldots$ \\
\hline poh sp. & Pohlia sp. (cf. nutans) & 15 & 1 & 15.0 & 201.1 & 346.6 & 492.1 \\
\hline pol str & Polytrichum strictum & 29 & 6 & 16.1 & 227.6 & 352.7 & 477.8 \\
\hline pti cri & Ptilium crista-castrensis & 1 & 4 & 1.0 & $\ldots$ & 268.0 & $\ldots$ \\
\hline pti pul & Ptilidium pulcherrimum & 1 & 1 & 1.0 & $\ldots$ & 294.0 & $\ldots$ \\
\hline san unc & Sanionia uncinata & $\cdots$ & $\cdots$ & $\cdots$ & $\cdots$ & $\ldots$ & $\ldots$ \\
\hline sca sp. & Scapania sp. & 6 & 5 & 4.7 & -5.8 & 17.1 & 40.0 \\
\hline $\operatorname{sco} \operatorname{sco}$ & Scorpidium scorpioides & $\cdots$ & $\cdots$ & $\cdots$ & $\cdots$ & $\cdots$ & $\cdots$ \\
\hline sph ang & Sphagnum angustifolium & 57 & 8 & 44.7 & 123.8 & 214.4 & 305.0 \\
\hline sph ann & S. annulatum & $\cdots$ & $\cdots$ & $\cdots$ & $\cdots$ & $\cdots$ & $\cdots$ \\
\hline sph cap & S. capillifolium & 33 & 8 & 23.8 & 110.5 & 212.8 & 315.1 \\
\hline sph cen & S. centrale & 5 & 5 & 3.8 & -28.5 & 64.0 & 156.5 \\
\hline sph com & S. compactum & $\ldots$ & $\ldots$ & $\ldots$ & $\ldots$ & $\ldots$ & $\ldots$ \\
\hline sph fal & S. fallax & 24 & 8 & 19.3 & 39.3 & 108.3 & 177.3 \\
\hline sph fle & S. flexuosum & $\cdots$ & $\cdots$ & $\cdots$ & $\cdots$ & $\cdots$ & $\cdots$ \\
\hline sph fus & S. fuscum & 38 & 8 & 32.1 & 230.1 & 361.8 & 493.5 \\
\hline sph lin & S. lindbergii & $\cdots$ & $\cdots$ & $\cdots$ & $\ldots$ & $\cdots$ & $\cdots$ \\
\hline sph mag & S. magellanicum & 78 & 8 & 50.5 & 98.1 & 221.8 & 345.5 \\
\hline sph maj & S. majus & 4 & 8 & 4.0 & 13.7 & 28.8 & 43.9 \\
\hline sph pla & S. platyphyllum & $\cdots$ & $\cdots$ & $\cdots$ & $\cdots$ & $\cdots$ & $\cdots$ \\
\hline sph pul & S. pulchrum & $\cdots$ & $\ldots$ & $\ldots$ & $\ldots$ & $\ldots$ & $\ldots$ \\
\hline sph rus & S. russowii & 8 & 8 & 5.7 & 214.7 & 291.2 & 367.7 \\
\hline sph subn & S. subnitens & $\ldots$ & $\ldots$ & $\ldots$ & $\ldots$ & $\ldots$ & $\ldots$ \\
\hline sph ten & S. tenerum & $\ldots$ & $\cdots$ & $\cdots$ & $\cdots$ & $\ldots$ & $\ldots$ \\
\hline sph war & S. warnstorfii & 3 & 4 & 2.5 & 69.8 & 115.9 & 162.0 \\
\hline tom fal & Tomenthypnum falcifolium & 9 & 3 & 7.1 & 43.6 & 160.4 & 277.2 \\
\hline tom nit & T. nitens & $\cdots$ & $\cdots$ & $\cdots$ & $\cdots$ & $\cdots$ & $\ldots$ \\
\hline war exa & Warnstorfia exannulatus & 8 & 8 & 5.7 & -12.5 & 13.8 & 40.1 \\
\hline
\end{tabular}

peat, which holds moisture more efficiently (Andrus 1986). Less moisture in the peat at similar heights above the water table could result in greater oxidation of the $\mathrm{CH}_{4}$ produced below the water table and lower fluxes to the atmosphere.

\section{Weighted averaging regression and calibration}

The optima of bryophyte species for mean watertable position in the Clay Belt and Labrador Trough peatlands are ordered very similarly to species in studies of bryophyte niches elsewhere in North
America and Europe. The Sphagnum species, with few exceptions, have a predictable order along the height gradient in all northern peatlands. The order reported here (Figs. 4 and 6) from highest to lowest in relation to mean water-table position is $S$. fuscum $>$ S. magellanicum, $S$. russowii, S. capillifolium, $S$. angustifolium $>S$. fallax, S. majus, S. lindbergii, S. pulchrum, S. annulatum, S. platyphyllum. The same order, with selected species from this list depending on the region, has been reported elsewhere (Andrus et al. 1983, Sjörs 1983, Vitt and Slack 
(in transformed units; see Fig. 5); $N_{2}=$ effective number of occurrences (Hill 1973); HMWT = height above mean water table. For HMWT and $\mathrm{CH}_{4}$ flux, given are WA optimum \pm WA tolerance for taxa with $>1$ occurrence.

\begin{tabular}{|c|c|c|c|c|c|c|c|c|c|c|c|}
\hline \multirow{2}{*}{\multicolumn{3}{|c|}{$\frac{\text { Clay belt }}{\mathrm{CH}_{4}\left(\mathrm{mg} \cdot \mathrm{m}^{-2} \cdot \mathrm{d}^{-1}\right)}$}} & \multicolumn{9}{|c|}{ Labrador Trough } \\
\hline & & & \multirow[b]{2}{*}{$N$} & \multirow[b]{2}{*}{ Max } & \multirow[b]{2}{*}{$\mathrm{N}_{2}$} & \multicolumn{3}{|c|}{ HMWT (mm) } & \multicolumn{3}{|c|}{$\mathrm{CH}_{4}\left(\mathrm{mg} \cdot \mathrm{m}^{-2} \cdot \mathrm{d}^{-1}\right)$} \\
\hline Opt - tol & Optimum & $\mathrm{Opt}+\mathrm{tol}$ & & & & Opt - tol & Optimum & $\mathrm{Opt}+\mathrm{tol}$ & Opt - tol & Optimum & $\mathrm{Opt}+$ tol \\
\hline 2.0 & 8.2 & 34.9 & 11 & 6 & 5.6 & 85.0 & 133.8 & 182.6 & 0.1 & 0.8 & 5.3 \\
\hline$\ldots$ & $\ldots$ & $\ldots$ & 1 & 1 & 1.0 & $\ldots$ & 80.0 & $\ldots$ & $\ldots$ & 1.3 & $\ldots$ \\
\hline$\ldots$ & $\ldots$ & $\ldots$ & 1 & 6 & 1.0 & $\ldots$ & 49.0 & $\ldots$ & $\ldots$ & 23.7 & $\ldots$ \\
\hline 20.7 & 78.4 & 305.4 & 31 & 6 & 19.9 & 9.1 & 67.5 & 125.9 & 1.3 & 7.4 & 42.1 \\
\hline$\ldots$ & $\ldots$ & $\ldots$ & 10 & 7 & 5.8 & 12.4 & 56.8 & 101.2 & 0.1 & 1.0 & 14.7 \\
\hline$\ldots$ & 182.9 & $\ldots$ & $\ldots$ & $\ldots$ & $\ldots$ & $\ldots$ & $\ldots$ & $\ldots$ & $\ldots$ & $\ldots$ & $\ldots$ \\
\hline$\ldots$ & $\ldots$ & $\ldots$ & 7 & 5 & 4.9 & -38.8 & 10.7 & 60.2 & 3.5 & 5.4 & 8.3 \\
\hline 10.1 & 30.8 & 96.6 & 51 & 8 & 40.7 & -66.2 & -4.5 & 57.1 & 9.2 & 29.1 & 94.2 \\
\hline 30.4 & 77.3 & 202.1 & $\ldots$ & $\ldots$ & $\ldots$ & $\ldots$ & $\ldots$ & $\ldots$ & $\cdots$ & $\ldots$ & $\cdots$ \\
\hline 1.1 & 2.0 & 3.5 & $\ldots$ & $\ldots$ & $\ldots$ & $\ldots$ & $\ldots$ & $\ldots$ & $\ldots$ & $\ldots$ & $\ldots$ \\
\hline$\cdots$ & $\cdots$ & $\cdots$ & 2 & 1 & 2.0 & 292.0 & 324.5 & 357.0 & 0.1 & 0.2 & 0.5 \\
\hline$\ldots$ & $\ldots$ & $\ldots$ & 1 & 8 & 1.0 & $\ldots$ & 80.0 & $\ldots$ & $\ldots$ & 1.3 & $\ldots$ \\
\hline$\ldots$ & $\ldots$ & $\ldots$ & 8 & 6 & 6.6 & -26.2 & 14.7 & 55.6 & 0.5 & 2.6 & 15.1 \\
\hline$\ldots$ & $\ldots$ & $\ldots$ & 7 & 7 & 5.8 & 31.1 & 62.0 & 92.9 & 3.1 & 7.3 & 17.2 \\
\hline$\ldots$ & $\ldots$ & $\ldots$ & 2 & 5 & 1.4 & -26.6 & 10.7 & 48.0 & 5.6 & 10.2 & 18.8 \\
\hline$\ldots$ & $\ldots$ & $\ldots$ & 4 & 6 & 2.6 & -18.5 & 5.2 & 28.9 & 2.8 & 3.9 & 5.7 \\
\hline$\ldots$ & $\ldots$ & $\ldots$ & 2 & 3 & 2.0 & 4.0 & 55.0 & 106.0 & 2.6 & 8.4 & 28.0 \\
\hline 2.9 & 14.4 & 71.8 & 14 & 8 & 8.3 & 50.7 & 115.7 & 180.7 & 0.7 & 2.7 & 10.2 \\
\hline$\ldots$ & $\ldots$ & $\ldots$ & 1 & 5 & 1.0 & $\ldots$ & 79.0 & $\ldots$ & $\ldots$ & 3.7 & $\ldots$ \\
\hline$\ldots$ & $\cdots$ & $\ldots$ & 8 & 8 & 4.1 & 23.3 & 89.9 & 156.6 & 0.2 & 0.7 & 3.0 \\
\hline$\ldots$ & $\ldots$ & $\ldots$ & 2 & 1 & 2.0 & $\ldots$ & 77.5 & $\ldots$ & $\ldots$ & 0.5 & $\ldots$ \\
\hline 1.1 & 3.5 & 11.1 & 3 & 8 & 1.5 & 313.0 & 341.9 & 370.8 & 0.4 & 0.5 & 0.6 \\
\hline$\ldots$ & 4.4 & $\ldots$ & $\ldots$ & $\ldots$ & $\ldots$ & $\ldots$ & $\ldots$ & $\ldots$ & $\ldots$ & $\ldots$ & $\ldots$ \\
\hline 1.1 & 3.7 & 12.3 & 13 & 5 & 7.8 & 25.4 & 144.4 & 263.4 & 0.3 & 1.4 & 5.8 \\
\hline 1.0 & 3.5 & 12.4 & 2 & 1 & 2.0 & 100.0 & 152.0 & 204.0 & 0.3 & 2.0 & 14.6 \\
\hline$\ldots$ & 8.3 & $\ldots$ & $\ldots$ & $\ldots$ & $\ldots$ & $\ldots$ & $\ldots$ & $\ldots$ & $\cdots$ & $\ldots$ & $\cdots$ \\
\hline$\ldots$ & 10.0 & $\ldots$ & $\ldots$ & $\ldots$ & $\ldots$ & $\ldots$ & $\ldots$ & $\ldots$ & $\ldots$ & $\ldots$ & $\ldots$ \\
\hline$\ldots$ & $\ldots$ & $\ldots$ & 1 & 1 & 1.0 & $\ldots$ & 106.0 & $\ldots$ & $\ldots$ & 2.6 & $\ldots$ \\
\hline 34.6 & 49.8 & 73.5 & 8 & 4 & 5.5 & 22.0 & 82.9 & 143.8 & 1.6 & 5.5 & 18.4 \\
\hline$\ldots$ & $\ldots$ & $\ldots$ & 6 & 8 & 5.7 & -8.9 & 2.3 & 13.5 & 4.5 & 5.7 & 7.3 \\
\hline 2.4 & 8.2 & 28.0 & 15 & 6 & 8.6 & 874 & 167.4 & 247.5 & 0.4 & 1.5 & 5.1 \\
\hline$\ldots$ & $\ldots$ & $\ldots$ & 12 & 6 & 6.5 & -54.7 & -14.6 & 25.6 & 13.9 & 41.8 & 128.6 \\
\hline 3.9 & 13.5 & 47.9 & $\ldots$ & $\ldots$ & $\ldots$ & $\ldots$ & $\ldots$ & $\ldots$ & $\ldots$ & $\ldots$ & $\ldots$ \\
\hline 8.2 & 29.1 & 105.2 & $\ldots$ & $\ldots$ & $\ldots$ & $\ldots$ & $\ldots$ & $\ldots$ & $\cdots$ & $\ldots$ & $\ldots$ \\
\hline$\ldots$ & $\ldots$ & $\ldots$ & 5 & 6 & 4.1 & 2.3 & 44.2 & 86.0 & 5.4 & 18.2 & 62.4 \\
\hline 20.5 & 49.8 & 123.8 & 5 & 8 & 2.1 & -2.3 & 3.1 & 8.5 & 60.4 & 74.4 & 94.2 \\
\hline$\ldots$ & $\ldots$ & $\ldots$ & 4 & 6 & 2.1 & 67.8 & 115.4 & 163.1 & 1.6 & 5.8 & 22.2 \\
\hline 1.2 & 3.6 & 11.2 & 5 & 8 & 5.0 & 265.5 & 297.6 & 329.7 & 0.2 & 0.4 & 0.9 \\
\hline$\cdots$ & $\ldots$ & $\ldots$ & 15 & 8 & 12.3 & -13.7 & 6.8 & 27.2 & 24.9 & 43.9 & 79.5 \\
\hline 2.2 & 9.8 & 44.7 & $\ldots$ & $\ldots$ & $\ldots$ & $\ldots$ & $\ldots$ & $\ldots$ & $\ldots$ & $\ldots$ & $\ldots$ \\
\hline 143.1 & 157.8 & 179.7 & $\ldots$ & $\ldots$ & $\ldots$ & $\ldots$ & $\ldots$ & $\ldots$ & $\ldots$ & $\cdots$ & $\ldots$ \\
\hline$\ldots$ & $\ldots$ & $\ldots$ & 7 & 4 & 4.6 & -47.5 & -14.5 & 18.6 & 7.0 & 22.4 & 73.2 \\
\hline$\ldots$ & $\ldots$ & $\ldots$ & 12 & 8 & 9.4 & 16.5 & 31.1 & 45.7 & 8.5 & 21.0 & 52.9 \\
\hline 2.2 & 5.3 & 12.5 & 18 & 8 & 14.5 & 87.9 & 138.1 & 188.3 & 0.8 & 2.7 & 9.3 \\
\hline$\ldots$ & $\ldots$ & $\ldots$ & 5 & 8 & 4.3 & 32.2 & 52.5 & 72.8 & 7.4 & 9.7 & 12.9 \\
\hline$\ldots$ & $\ldots$ & $\ldots$ & 1 & 2 & 1.0 & $\ldots$ & 97.0 & $\ldots$ & $\ldots$ & 2.3 & $\ldots$ \\
\hline 28.6 & 37.6 & 50.6 & 11 & 8 & 8.3 & 71.4 & 146.7 & 222.0 & 0.0 & 0.2 & 1.5 \\
\hline 4.9 & 14.9 & 46.5 & 1 & 6 & 1.0 & $\ldots$ & 160.0 & $\ldots$ & $\ldots$ & 5.3 & $\ldots$ \\
\hline$\ldots$ & $\ldots$ & $\ldots$ & 5 & 8 & 3.2 & 188.2 & 233.6 & 279.0 & 0.1 & 0.5 & 3.3 \\
\hline 39.0 & 57.6 & 87.3 & 25 & 8 & 16.6 & -50.6 & -23.6 & 3.3 & 14.6 & 35.8 & 89.7 \\
\hline
\end{tabular}

1984, Rydin and McDonald 1985, Janssens 1990, Gignac 1992).

The tolerances for mean water-table position also show trends similar to studies of bryophytes in other regions. The smallest tolerances, particularly in the Clay Belt (Fig. 4), are found with the wettest indicator species such as Sphagnum majus and Warnstorfia exannulatus, while lawn species such as Sphagnum capillifolium, S. magellanicum, and Aulocomnium palustre have wider tolerances along the height gradient. The same pattern, which has been reported elsewhere (Vitt and Slack 1984, Gignac 1992), has been attributed to both physiological and competitive strategies of bryophytes (Clymo and Hayward 1982, Wagner and Titus 1984, Rydin 1985, Okland 1990, Gignac 1992).

The optima for $\log \mathrm{CH}_{4}$ flux in the Clay Belt (Fig. 4) shows that the order of species along the water table gradient is almost exactly the same order as for log $\mathrm{CH}_{4}$ flux optima. This confirms the strong interdependence of water table position and $\mathrm{CH}_{4}$ flux and that bryophytes show similar distributions to both variables. The tolerances for $\log \mathrm{CH}_{4}$ flux are wider than 


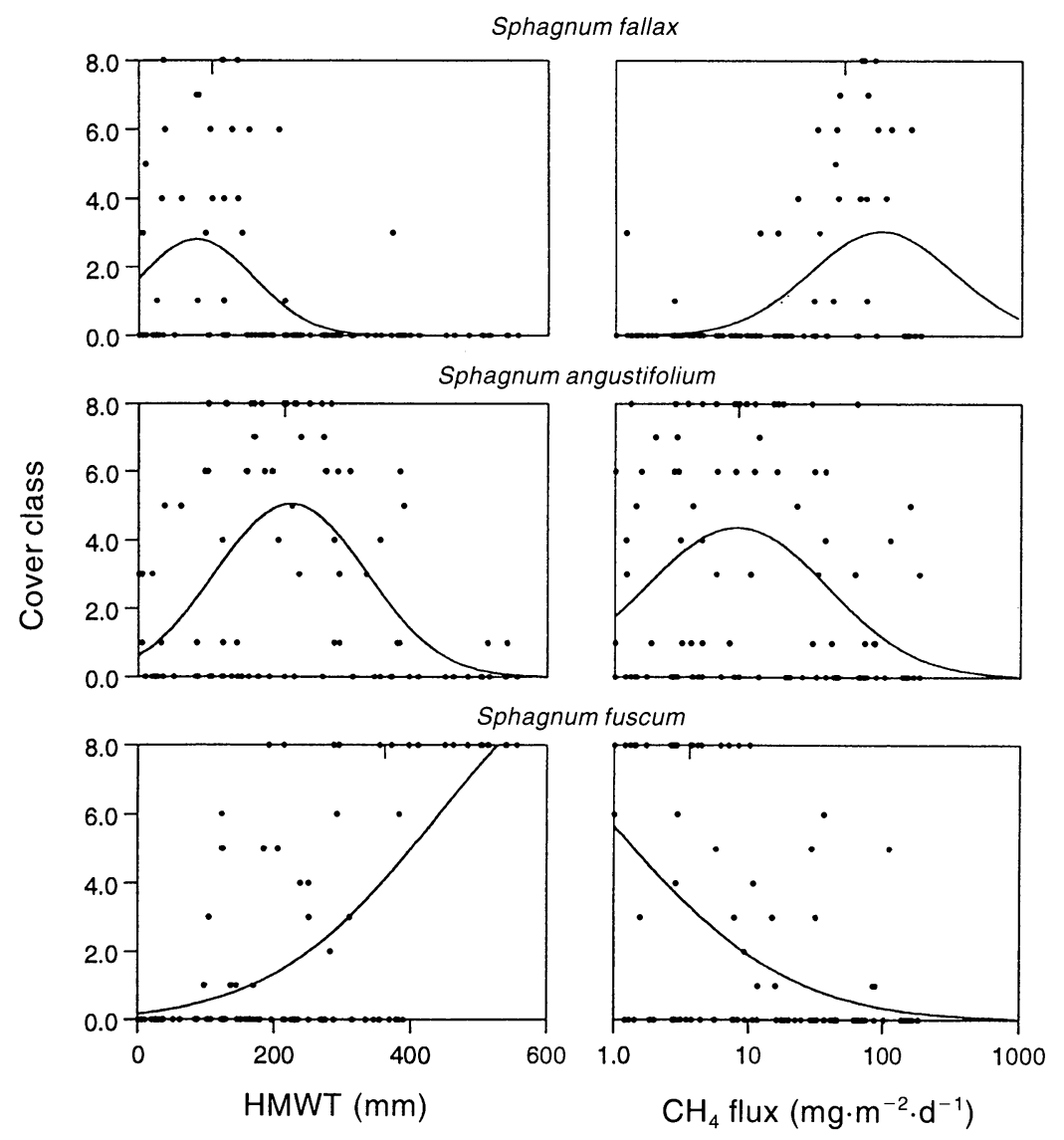

FIG. 5. Species distributions of typical hummock (S. fuscum), lawn (S. angustifolium) and carpet (S. fallax) Sphagnum species in the Clay Belt in relation to HMWT and $\mathrm{CH}_{4}$ flux. Graphs show $\log _{10}$-transformed abundances and fitted Gaussian response curves (ter Braak and Looman 1986). Optima derived by weighted averaging are indicated by a tick on the top axis. Cover classes: $1=0-1 \%, 2=>1-2 \%, 3=>2-5 \%, 4=>5-10 \%, 5=>10-25 \%, 6=>25-50 \%, 7=>50-75 \%$, $8=>75-100 \%$. Note the logarithmic scale on the $x$ axis.

for water table position, but they are widest in the midhummock and lawn range, the same pattern as for water table tolerances. There is no overlap between the ends of the $\log \mathrm{CH}_{4}$ flux gradient, suggesting that the best predictors of $\mathrm{CH}_{4}$ emission are species that occur at the driest and wettest ends of the spectrum. The total $\mathrm{CH}_{4}$ emission from a region is dominated by emissions from the wettest areas because of the $\log \mathrm{CH}_{4}$ flux scale. Therefore, estimating cover of high- $\mathrm{CH}_{4}$-flux bryophytes - the indicators of the wettest sites-is the most valuable predictive tool for estimating $\mathrm{CH}_{4}$ flux from a region's wetlands.

A similar ordering of species along the $\mathrm{CH}_{4}$ flux gradient is found in Labrador Trough peatlands (Fig. 6), although non-Sphagnum species that are restricted to rich pools are not in the same relative position along the $\mathrm{CH}_{4}$ flux gradient as they are along the height gradient. For example, Scorpidium scorpioides, Meesia longiseta, Limprichtia revolvens, and Cinclidium stygium are species restricted to rich fens (Slack et al. 1980). They are found in the richest pools in the Trough, yet they occur in an intermediate position along the $\mathrm{CH}_{4}$ flux gradient. The water table- $\mathrm{CH}_{4}$ flux relationship appears to break down in flooded sites where oxygen-rich groundwater may be facilitating $\mathrm{CH}_{4}$ oxidation within the water column. The $\mathrm{CH}_{4}$ fluxes from these rich pools are extremely low $(<10$ $\left.\mathrm{mg} \cdot \mathrm{m}^{-2} \cdot \mathrm{d}^{-1}\right)$. Greater hydraulic conductivity in peatlands underlain by dolomite (e.g., Astray), rather than shale or quartzite (e.g., Pelletier), may be responsible for faster movement of groundwater and replenishment of oxygen in the water column. In spite of the lack of correspondence between the species order for water table and $\mathrm{CH}_{4}$ flux for these rich-fen-pool species, the tolerances for $\log \mathrm{CH}_{4}$ flux are still small. This suggests that rich-fen-pool species, regardless of their low optimum $\mathrm{CH}_{4}$ flux values, are still good predictors. Future research should test the relationship of rich-fen-pool species in other regions to $\mathrm{CH}_{4}$ flux to see if the same pattern occurs. In other regions higher $\mathrm{CH}_{4}$ fluxes may occur if the mineral concentrations are high but oxygen concentrations are low. The Labrador Trough fens may have an unusually high oxygen content.

Although the predictive ability of bryophytes for 

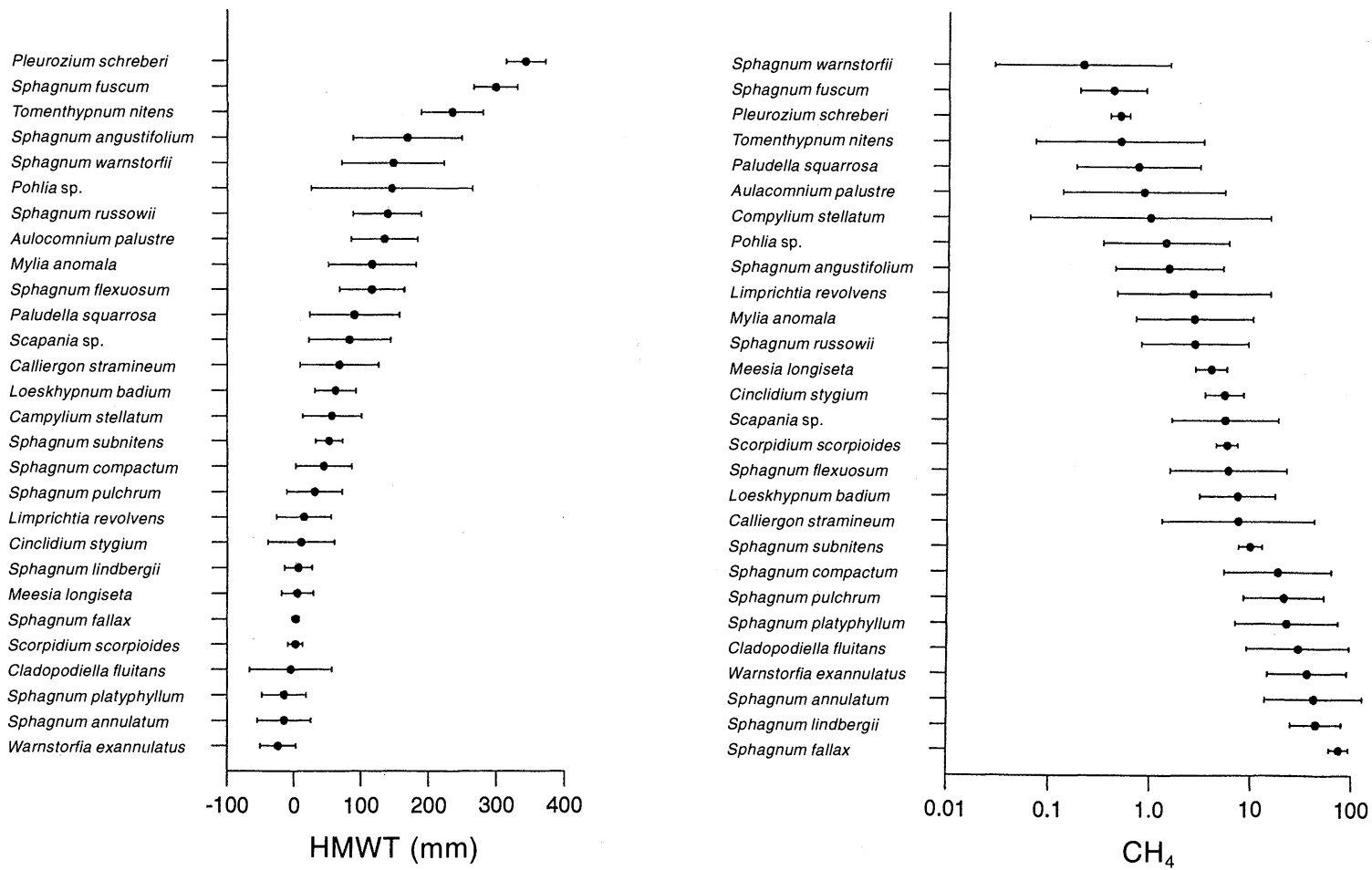

FIG. 6. Weighted average optima (central point: abundance-weighted means) and tolerances (bars: abundance-weighted SDs) of Labrador Trough bryophytes for height above mean water table (HMWT) and $\mathrm{CH}_{4}$ flux for all taxa with $>2$ occurrences.

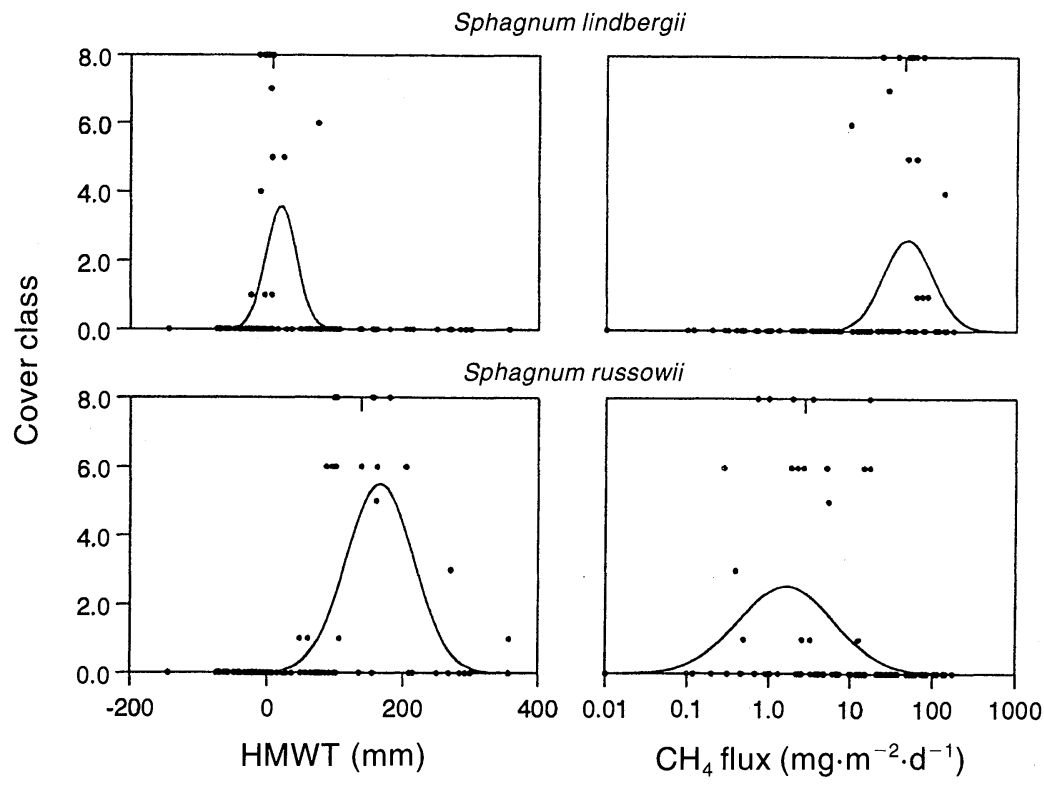

FIG. 7. Species distributions of typical low hummock (Sphagnum russowii) and carpet (S. lindbergii) species in the Labrador Trough in relation to HMWT and $\mathrm{CH}_{4}$ flux. Graphs show $\log _{10}$-transformed abundances and fitted Gaussian response curves (ter Braak and Looman 1986). Optima derived by weighted averaging are indicated by a tick on the top axis. Cover classes: $1=0-1 \%, 2=>1-2 \%, 3=>2-5 \%, 4=>5-10 \%, 5=>10-25 \%, 6=>25-50 \%, 7=>50-75 \%, 8=>75-$ $100 \%$. Note the logarithmic scale on the $x$ axis. 
TABLE 3. Correlation coefficients $\left(r^{2}\right)$ and prediction error estimates (root mean squared error [RMSE]) for weightedaveraging (WA) regression based on observed vs. predicted values of bryophytes, height above mean water table (HMWT), and $\log \mathrm{CH}_{4}$ flux ( $n=98$ samples). Statistics are reported for WA and for WA with tolerance downweighting (WA-TOL).

\begin{tabular}{|c|c|c|c|c|}
\hline \multirow{2}{*}{$\begin{array}{c}\text { Factor } \\
\text { correlated } \\
\text { with } \\
\text { bryophytes }\end{array}$} & \multicolumn{2}{|c|}{ Clay Belt } & \multicolumn{2}{|c|}{ Labrador Trough } \\
\hline & $r^{2}$ & RMSE & $r^{2}$ & RMSE \\
\hline \multicolumn{5}{|l|}{ HMWT } \\
\hline $\begin{array}{l}\text { WA } \\
\text { WA-TOL }\end{array}$ & $\begin{array}{l}0.72 \\
0.75\end{array}$ & $\begin{array}{l}90.1 \\
83.3\end{array}$ & $\begin{array}{l}0.87 \\
0.88\end{array}$ & $\begin{array}{l}39.1 \\
37.8\end{array}$ \\
\hline \multicolumn{5}{|l|}{$\log \mathrm{CH}_{4}$ flux } \\
\hline $\begin{array}{l}\text { WA } \\
\text { WA-TOL }\end{array}$ & $\begin{array}{l}0.65 \\
0.70\end{array}$ & $\begin{array}{l}0.49 \\
0.44\end{array}$ & $\begin{array}{l}0.77 \\
0.79\end{array}$ & $\begin{array}{l}0.49 \\
0.46\end{array}$ \\
\hline
\end{tabular}

$\mathrm{CH}_{4}$ flux within each of the two regions is good, it is not possible to use species values from one region and extropolate to another. Many of the same species that occur in the Clay Belt also occur in the Labrador Trough, yet their optimum $\mathrm{CH}_{4}$ fluxes are different. At the low end of the $\log \mathrm{CH}_{4}$ flux scale the species optima are not that different. For example Pleurozium schreberi, Sphagnum fuscum, and Polytrichum strictum all have optimum $\mathrm{CH}_{4}$ fluxes of $<5 \mathrm{mg} \cdot \mathrm{m}^{-2} \cdot \mathrm{d}^{-1}$. The wetter end of the $\mathrm{CH}_{4}$ flux gradient shows some significant differences, however. Warnstorfia exannulatus in the Clay Belt has an optimum $\mathrm{CH}_{4}$ flux of $80 \mathrm{mg} \cdot \mathrm{m}^{-2} \cdot \mathrm{d}^{-1}$, while the same species in the Labrador Trough has an optimum of only $50 \mathrm{mg} \cdot \mathrm{m}^{-2} \cdot \mathrm{d}^{-1}$. Sphagnum majus in the Clay Belt has an optimum of $160 \mathrm{mg} \cdot \mathrm{m}^{-2} \cdot \mathrm{d}^{-1}$, while its ecological equivalents in terms of water table position, $S$. annulatum and $S$. lindbergii, have optima of only $60-70 \mathrm{mg} \cdot \mathrm{m}^{-2} \cdot \mathrm{d}^{-1}$.

The reasons for the differences in $\mathrm{CH}_{4}$ flux optima for similar species between regions are probably multifaceted. Since $\mathrm{CH}_{4}$ emission and bryophyte distribution are controlled by a variety of biogeochemical and climatic processes, it is unlikely that a perfect predictive relationship would occur between regions. However, within a region the suite of wetlands are derived from similar geologic and hydrologic processes; consequent$1 y$, the species parameters between wetlands should be more similar. Multi-year data sets for the Labrador Trough show interannual variability in $\mathrm{CH}_{4}$ flux in the Labrador Trough peatlands (Moore et al. 1990, Windsor et al. 1992, Bubier submitted). However, regardless of year or region, the relative position of each bryophyte species along the $\mathrm{CH}_{4}$ flux gradient remains the same.

\section{Estimating prediction error for $\mathrm{CH}_{4}$ emission}

Since both water table position and bryophytes are good predictors of $\log \mathrm{CH}_{4}$ flux, it is worth examining the relative merits of using bryophytes vs. water table when estimating $\mathrm{CH}_{4}$ emissions from northern peatlands. A comparison of the regression statistics for pre- dicting $\log \mathrm{CH}_{4}$ flux from water table position and bryophytes (Fig. 1, Table 3) shows that the two variables are similar in their predictive power. Correlations between water table position and $\mathrm{CH}_{4}$ flux are 0.68 and 0.62 for the Clay Belt and the Labrador Trough, respectively, while the $r^{2}$ values for bryophytes based on weighted averaging regression (WA-TOL) are 0.70 and 0.79 , respectively. The root mean squared error of prediction (RMSE) for $\log \mathrm{CH}_{4}$ flux is very similar for HMWT (height above mean water table) and bryophytes $(0.38-0.49)$ in both regions.

However, when examining the temporal component, bryophytes are better predictors than water table position. Mean water-table position is an average of large spatial and temporal fluctuations over the entire frostfree season. The average standard deviation in water table position around the mean for a peatland site (which factors in both the seasonal variations, based on weekly measurements, and spatial microtopographic variability) is $\approx 240 \mathrm{~mm}$ for the Clay Belt and $135 \mathrm{~mm}$ for the Labrador Trough. The SD does not account for short-term fluctuations, which can be substantial after significant rain events. A one-time measurement of water table position could under- or overestimate the mean position at an individual chamber location by as much as $100 \%$ in some peatlands. On the other hand, bryophytes can be sampled once during the season; their relative cover does not change because they reflect integrated environmental parameters over longer periods of time than days or months.

A second advantage of using bryophytes rather than water table position to predict $\mathrm{CH}_{4}$ flux is that they can be remotely sensed. Recent studies of the different reflectance values of bryophytes in the Labrador Trough peatlands (Windsor 1993) and of different Sphagnum species (Vogelmann 1992) suggests that with fine-resolution techniques, we may be able to estimate the cover of different bryophytes across large areas with only minimal field verification. This possibility depends on taking early spring images before the vascular vegetation obscures the bryophyte layer. This technique would probably be effective only in open peatlands where tree cover is minimal. Remote sensing of mean water-table position is not realistic given the temporal variability of hydrologic systems, the small-scale variation in water table position in uneven hummock-hollow microtopography, and differential responses to precipitation in floating vs. non-floating peat surfaces.

In addition to their role in predicting current methane emissions from peatlands, bryophytes may be useful in palaeoenvironmental reconstructions of methane emission using macrofossils in peat profiles. Reconstructions have already been successful for $\mathrm{pH}$ and water table position using the WA calibration technique (Janssens et al. 1992). Bryophytes will also be a useful tool for biological monitoring of future methane emissions from peatlands, as peatland hydrology responds to climate change. 

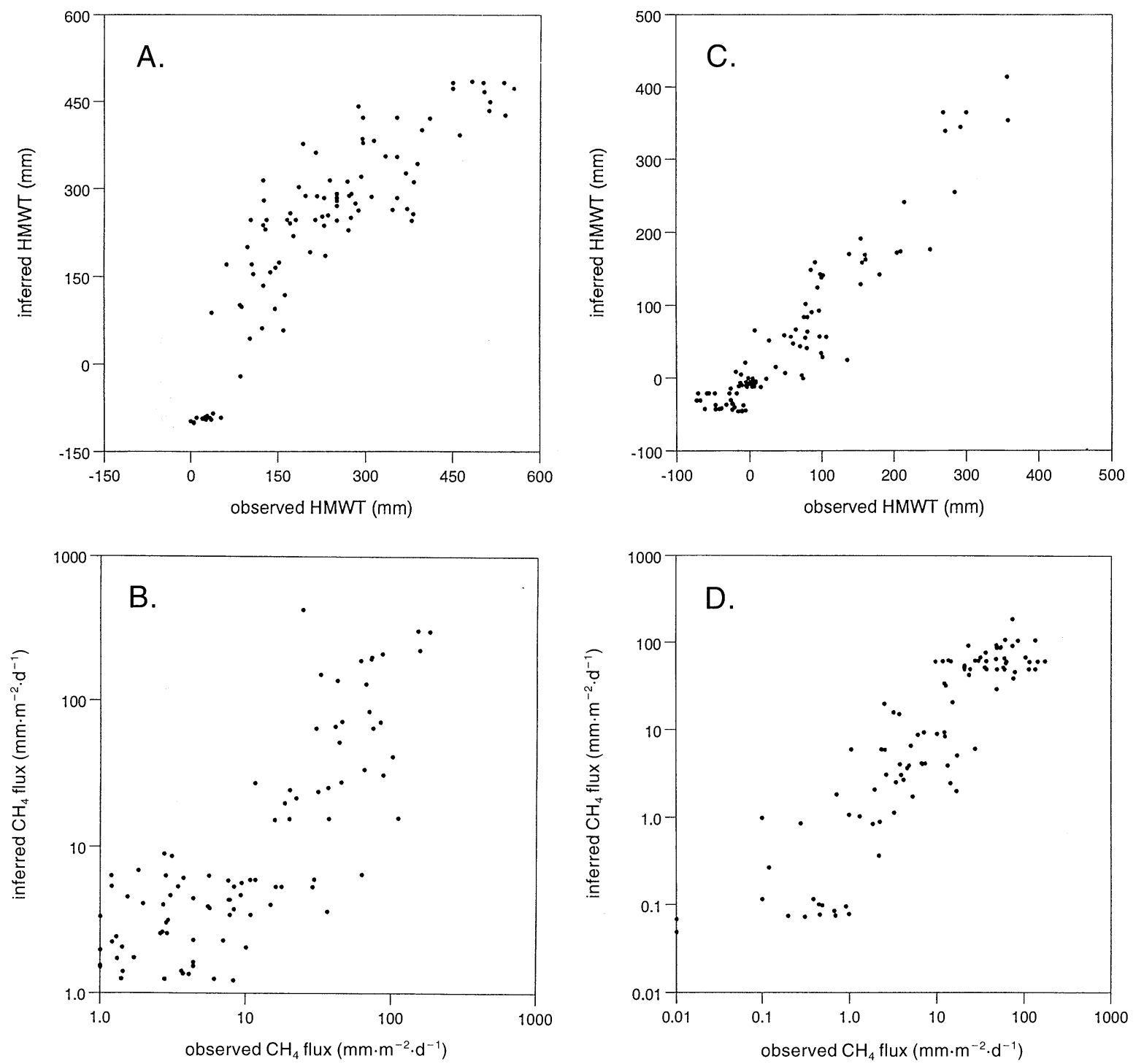

FIG. 8. Plots of observed vs. inferred environmental values (height above mean water table [HMWT] and $\mathrm{CH}_{4}$ flux) for individual bryophyte plots in northern Canada based on weighted average calibration with tolerance downweighting. See Table 3B for RMSE and $r^{2}$ values. Diagrams include model estimates for the Clay Belt (A, B) and the Labrador Trough (C, D). Note the logarithmic scale in parts B and D.

\section{ACKNOWLEDGMENTS}

We would like to thank R. Ash, D. Barr, A. Costello, M. Dalva, S. Glenn, A. Heyes, X. Hu, W. Quinton, K. Savage, and J. Windsor for assistance in the laboratory and the field; NSERC Strategic and Operating Grants (to T. R. Moore) and Max Bell Fellowships of McGill University (to J. L. Bubier) for funding this research; J. Janssens for assistance with bryophyte identification and research methods; the McGill Subarctic Research Station for research facilities in Schefferville, Quebec; C. McQueen for laboratory facilities at Johnson State College, Vermont; D. Gignac, M. Lechowicz, D. Peteet, N. Roulet, D. Vitt, and M. Waterway for fruitful discussions; and three anonymous reviewers for commenting on this manuscript.

\section{Literature Cited}

Anderson, L. E. 1990. A checklist of Sphagnum in North America north of Mexico. The Bryologist 93:500-501.
Anderson, L. E., H. A. Crum, and W. R. Buck. 1990. List of the mosses of North America north of Mexico. Bryologist 93:448-499.

Andrus, R. E. 1986. Some aspects of Sphagnum ecology. Canadian Journal of Botany 64:416-426.

Andrus, R. E., D. J. Wagner, and J. E. Titus. 1983. Vertical distribution of Sphagnum mosses along hummock-hollow gradients. Canadian Journal of Botany 61:3128-3139.

Birks, H. J. B., J. M. Line, S. Juggins, A. C. Stevenson, and C. J. F. ter Braak. 1990. Diatoms and $\mathrm{pH}$ reconstruction. Philosophical Transactions of the Royal Society of London B 327:263-278.

Boelter, D. H. 1965. Hydraulic conductivity of peats. Soil Science 100:227-231.

Borcard, D., P. Legendre, and P. Drapeau. 1992. Partialling out the spatial component of ecological variation. Ecology 73: $1045-1055$.

Bubier, J. L. In press. The relationship of vegetation to meth- 
ane emission and hydro-chemical gradients in northern peatlands. Journal of Ecology.

Bubier, J., A. Costello, T. R. Moore, N. T. Roulet, and K. Savage. 1993b. Microtopography and methane flux in boreal peatlands, northern Ontario, Canada. Canadian Journal of Botany 71:1056-1063.

Bubier, J. L., T. R. Moore, and N. T. Roulet. 1993a. Methane emissions from mid-boreal wetlands of northern Ontario, Canada. Ecology 74:2240-2254.

Cicerone, R. J., and R. S. Oremland. 1988. Biogeochemical aspects of atmospheric methane. Global Biogeochemical Cycles 2:299-327.

Clymo, R. S., and P. M. Hayward. 1982. The ecology of Sphagnum. Pages 229-289 in A. J. E. Smith, editor. Bryophyte ecology. Chapman \& Hall, London, England.

Crill, P. M., K. B. Bartlett, R. C. Harriss, E. Gorham, E. S. Verry, D. I. Sebacher, L. Madzer, and W. Sanner. 1988. Methane flux from Minnesota peatlands. Global Biogeochemical Cycles 2:371-384.

Crill, P., K. B. Bartlett, and N. Roulet. 1992. Methane flux from boreal peatlands. Suo 43:173-182.

Daubenmire, R. F. 1968. Plant communities: a textbook of plant synecology. Harper \& Row, New York, New York, USA.

Dimroth, E. 1978. Labrador Trough area between latitudes $54^{\circ} 30^{\prime} \mathrm{N}$ and $56^{\circ} 30^{\prime} \mathrm{N}$, Quebec (Province). Rapport Geologic 193. Ministère des richesses naturelles, Direction générale des mines, Service de l'exploration géologique, Quebec City, Quebec, Canada.

Dise, N. B., E. Gorham, and E. S. Verry. 1993. Environmental factors controlling methane emissions from peatlands in northern Minnesota. Journal of Geophysical Research 98:10 583-10 594.

Dixit, S. S., B. F. Cumming, H. J. B. Birks, J. P. Smol, J. C. Kingston, A. J. Uutala, D. F. Chrales, and K. E. Cambrun. 1993. Diatom assemblages from Adirondack Lakes (New York, U.S.A.) and the development of inference models for retrospective environmental assessment. Journal of Palaeolimnology 8:27-47.

Dunfield, P., K. Knowles, R. Dumont, and T. Moore. 1993. Methane production and consumption in temperate and subarctic peat soils: response to temperature and $\mathrm{pH}$. Soil Biology and Biochemistry 25:321-326.

Fritz, S. C., S. Juggins, R. W. Battarbee, and D. R. Engstrom. 1991. Reconstruction of past changes in salinity and climate using a diatom-based transfer function. Nature 352: 706-708.

Gignac, L. D. 1992. Niche structure, resource partitioning, and species interactions of mire bryophytes relative to climatic and ecological gradients in western Canada. Bryologist 95:406-418.

Hill, M. O. 1973. Diversity and evenness: a unifying notation and its consequences. Ecology 54:427-432.

Hill, M. O., and H. G. Gauch. 1980. Detrended correspondence analysis, an improved ordination technique. Vegetatio 42:47-58.

Janssens, J. A. 1990. Ecology of peatland bryophytes and paleoenvironmental reconstruction of peatlands using fossil bryophytes. Methods manual. Department of Ecology, Evolution and Behavior, University of Minnesota, Saint Paul, Minnesota, USA.

Janssens, J. A., B. C. S. Hansen, P. H. Glaser, and C. Whitlock. 1992. Development of a raised bog complex in northern Minnesota. Pages 189-221 in H. E. Wright, Jr., B. Coffin, and N. Aaseng, editors. Patterned peatlands of northern Minnesota. University of Minnesota Press, Minneapolis, Minnesota, USA.

Jongman, R. G. H., C. J. F. ter Braak, and O. F. R. van Tongeren. 1987. Data analysis in community and land- scape ecology. Centre for Agricultural Publishing and Documentation, Wageningen, The Netherlands.

King, G. M. 1990. Dynamics and controls of methane oxidation in a Danish wetland sediment. FEMS (Federation of European Microbiological Societies) Microbiology Ecology 74:309-324.

Lechowicz, M. J., and M. S. Adams. 1978. Diurnal and seasonal structure of the climate at Schefferville, Quebec. Arctic and Alpine Research 10:95-104.

Moore, T. R., and M. Dalva. 1993. The influence of temperature and water table position on carbon dioxide and methane emissions from laboratory columns of peatland soils. Journal of Soil Science 44:651-664.

Moore, T. R., and R. Knowles. 1990. Methane emissions from fen, bog and swamp peatlands in Quebec. Biogeochemistry 11:45-61.

Moore, T. R., and N. T. Roulet. 1991. A comparison of dynamic and static chambers for methane emission measurements from subarctic fens. Atmosphere-Ocean 29:102109.

Moore, T. R., and N. T. Roulet. 1993. Methane flux: water table relations in northern wetlands. Geophysical Research Letters 20:587-590.

Moore, T. R., N. Roulet, and R. Knowles. 1990. Spatial and temporal variations of methane flux from subarctic/northern boreal fens. Global Biogeochemical Cycles 4:29-46.

Morrissey, L. A., and G. P. Livingston. 1992. Methane emissions from Alaskan arctic tundra: an assessment of local spatial variability. Journal of Geophysical Research 97: $16661-16670$.

Nilsson, M., and E. Bohlin. 1993. Methane and carbon dioxide concentrations in bogs and fens-with special reference to the effects of the botanical composition of the peat. Journal of Ecology 81:615-625.

Okland, R. H. 1990. A phytoecological study of the mire Northern Kisselbergmosen, SE Norway. III. Diversity and habitat niche relationships. Nordic Journal of Botany 10: 191-220.

Osborne, C. 1991. Statistical calibration: a review. International Statistical Review 59:309-336.

Riley, J. L. 1987. Peat and peatland resources of northeastern Ontario. Open file report 5631. Ontario Geological Survey, Ministry of Northern Mines and Development, Toronto, Ontario, Canada.

Roulet, N. T. 1991. Surface level and water table fluctuations in a subarctic fen. Arctic and Alpine Research 23:303-310.

Roulet, N., R. Ash, and T. R. Moore. 1992. Low boreal wetlands as a source of atmospheric methane. Journal of Geophysical Research 97:3739-3749.

Rydin, H. 1985. Effect of water level on desiccation of Sphagnum in relation to surrounding Sphagna. Oikos 45: 374-379.

Rydin, H., and A. J. S. McDonald. 1985. Tolerance of Sphagnum to water level. Journal of Bryology 13:571-578.

Sjörs, H. 1983. Mires of Sweden. Pages 69-94 in A. J. P. Gore, editor. Mires: swamp, bog, fen, and moor. Elsevier, Amsterdam, The Netherlands.

Slack, N. G. 1990. Bryophytes and ecological niche theory. Botanical Journal of the Linnean Society 104:187-213.

Slack, N. G., D. H. Vitt, and D. G. Horton. 1980. Vegetation gradients of minerotrophically rich fens in western Alberta. Canadian Journal of Botany 58:330-350.

Stotler, R., and B. Crandell-Stotler. 1977. Checklist of liverworts and hornworts of North America. Bryologist 80: 405-428.

ter Braak, C. J. F. 1986. Canonical correspondence analysis: a new eigenvector technique for multivariate direct gradient analysis. Ecology 67:1167-1179.

1990. CANOCO-a FORTRAN program for canonical community ordination by [partial][detrended][ca- 
nonical] correspondence analysis, principal components analysis and redundancy analysis. Version 3.1. TNO Institute of Applied Computer Science, Wageningen, The Netherlands.

ter Braak, C. J. F., and S. Juggins. 1993. Weighted averaging partial least squares regression (WA-PLS): an improved method for reconstructing environmental variables from species assemblages. Hydrobiologia 269/270:485-502.

ter Braak, C. J. F., and W. N. Looman. 1986. Weighted averaging, logistic regression and the Gaussian response model. Vegetatio 65:3-11.

ter Braak, C. J. F., and H. Van Dam. 1989. Inferring pH from diatoms: a comparison of old and new calibration methods. Hydrobiologia 178:209-233.

Vitt, D. H. 1990. Growth and production dynamics of boreal mosses over climatic, chemical and topographic gradients. Botanical Journal of the Linnean Society 104:35-39.

Vitt, D. H., and N. G. Slack. 1984. Niche diversification of Sphagnum relative to environmental factors in northern Minnesota peatlands. Canadian Journal of Botany 62:14091430 .

Vogelmann, J. E., and D. M. Moss. 1992. Spectral analysis in the genus Sphagnum using LANDSAT TM and high spectral resolution laboratory measurements. International Geoscience and Remote Sensing Symposium paper, IEEE Catalog Number 92CH 3041-1. Institute of Electrical and Electronics Engineers, New York, New York, USA.
Wagner, D. J., and J. E. Titus. 1984. Comparative desiccation tolerance of two Sphagnum mosses. Oecologia 62:182-187.

Walker, I. R., R. J. Mott, and J. P. Smol. 1991. AllerodYounger Dryas lake temperatures from midge fossils in Atlantic Canada. Science 253:1010-1012.

Waterway, M. J., M. J. Lechowicz, and T. R. Moore. 1984. Vegetation of the Schefferville region, Nouveau-Quebec. Future directions for research in Nouveau-Quebec. McGill Subarctic Research Paper Number 39. Centre for Northern Studies and Research, McGill University, Montreal, Quebec, Canada.

Whalen, S. C., and W. S. Reeburgh. 1992. Interannual variations in methane emissions: a four-year time-series at fixed sites. Global Biogeochemical Cycles 6:139-159.

Whiting, G. J., and J. P. Chanton. 1992. Plant-dependent $\mathrm{CH}_{4}$ emission in a subarctic Canadian fen. Global Biogeochemical Cycles 6:225-231.

Windsor, J. 1993. Methane emissions from the eastern temperate wetland region and spectral characteristics of subarctic fens. Thesis. Geography Department, McGill University, Montreal, Quebec, Canada.

Windsor, J., T. R. Moore, and N. T. Roulet. 1992. Episodic fluxes of methane from subarctic fens. Canadian Journal of Soil Science 72:441-452.

Zoltai, S. C. 1988. Wetland environments and classification. Pages 3-26 in National Wetlands Working Group. Wetlands of Canada. Ecological land classification series, number 24. Environment Canada, Sustainable Development Branch, Ottawa, Ontario, Canada. 